This is the peer reviewed version of the following article: Mottershead, D. N., Bray, M. J., Soar, P. J., and Farres, P. J. (2015) Characterisation of erosional features associated with tsunami terrains on rocky coasts of the Maltese islands. Earth Surf. Process. Landforms, doi: 10.1002/esp.3784, which has been published in final form at http://onlinelibrary.wiley.com/doi/10.1002/esp.3784/full . This article may be used for non-commercial purposes in accordance with Wiley Terms and Conditions for Self-Archiving

\title{
CHARACTERISATION OF EROSIONAL FEATURES ASSOCIATED WITH TSUNAMI TERRAINS ON ROCKY COASTS OF THE MALTESE ISLANDS
}

\section{Derek Mottershead, Malcolm Bray, Philip Soar, Paul Farres}

\section{Abstract:}

In recent years there has been a growing body of literature on depositional signatures associated with historic extreme waves on rocky coasts. Here, in the context of the Maltese islands, we place an innovative focus on evidence of erosional forms. The field evidence is concentrated along the NE flank of the islands at a topographically varied range of sites and up to an altitude of $13 \mathrm{~m}$. A range of forms is broadly classified in terms of their morphologies and the forces responsible for their formation. Sockets, eroded scarps, scoured terrains, clifftop erosion scars, swept terrains and spillways are interpreted as consequences of overwashing of the landscape by an extreme wave or waves. These forms are shown to be controlled by flow intensity, topography and lithology, and especially rock bedding and jointing. They comprise the source areas for associated depositional evidence allowing transport paths to be estimated, and may significantly enhance the reconstruction of extreme wave events. It is likely that similar (and additional) erosional forms are present elsewhere in the Mediterranean domain, where comparable lithological and topographic situations are exposed to extreme waves.

Keywords: Mediterranean, extreme waves, erosion features, boulder deposits, tsunami, Malta.

\section{Introduction}

There is a growing body of publications detailing the imprint of historic extreme wave events, including palaeotsunami, on Mediterranean coasts. The literature to date, however, concentrates largely on sedimentary materials, most frequently in the form of displaced boulders, but also ranging in size from sand to megaclasts. Clearly such clastic materials have been removed and transferred from their source locations and are, therefore, explicitly indicative of antecedent erosion. Despite this, there has been little attention paid to erosion features thus created or of their value in reconstructing the 
processes and forcing agents involved. Bryant \& Young (1996) present a pioneering study, whilst Bryant (1E 2001, 3E 2014) offers a stimulating, though not uncontentious, review (Felton \& Crook 2003, Dawson 2003). Otherwise, the treatment of erosion features within reviews of tsunami signatures is generally limited or absent, for example Scheffers and Kelletat (2003), Bourgeois (2009), Courtney et al., (2012).

Erosion of bedrock in the coastal zone can be accomplished by processes of both abrasion and joint block removal. Bedrock erosion by extreme waves, and their flows, is described by Nott \& Bryant (2003) and Bryant (2014; pp. 45-50). Studies of contemporary block removal and transport are presented by Hall et al., (2006), Knight et al., (2009) and Knight and Burningham (2011) from extreme wave environments and by Naylor \& Stephenson (2010), Stephenson \& Naylor (2011), Oliviera et al., (2011), Paris et al., (2011) and Dornbusch \& Robinson (2011) from temperate storm wave environments.

Modelling of boulder detachment by wave processes has been applied widely to estimate the characteristics of the waves responsible for subsequently deposited boulders (Nott 1997, 2003, Benner et al., 2010, Nandasena et al., 2011, Engel \& May 2012). In particular, models based on boulder axis dimensions are presented for the removal of joint-bounded boulders from scarp faces by shearing and lifting by a flow of water, and from bedrock surfaces by decompression forces following the passage of a large wave. Such models have been used by subsequent authors in attempting to discriminate the potential contribution of tsunami and storm waves in forming historic extreme wave boulder deposits (e.g. Noormets et al., 2004, Mastronuzzi et al., 2007, Scicchitano et al., 2007, Maouche et al., 2009, Pignatelli et al., 2009, Barbano et al., 2010, Benner et al., 2010, Shah-Hosseini et al., 2013). They have also been tested in relation to work carried out by recently observed tsunami (Bourgeois \& Mclnnes 2010, Goto et al., 2010) and storm waves (Mastronuzzi \& Sansó 2004, Goto et al., 2011).

Specific erosional forms postulated to be indicative of tsunami are documented by Nott \& Bryant (2003), and Bryant (2014 pp. 51-59) based largely on examples from the SE coast of Australia. Few other studies identify such forms elsewhere, although sculptured forms of postulated tsunamigenic origin are reported from California, USA (Aalto et al., 1999) and the Bristol Channel UK (Bryant and Haslett 2007). Review of this body of work has recommended that further research into these features is required to resolve uncertainties and validate some interpretations (Courtney et al., 2012). A specific area of concern is to differentiate the effects of high energy storm and/or swell waves from those of tsunami in 
generating erosion features. The tsunamigenic but fetch-restricted Mediterranean Sea lacks exposure to major oceanic swell waves, contrasting with Atlantic and Pacific coasts that experience extreme waves and also Caribbean coasts which experience hurricanegenerated waves.

The Mediterranean does, however, experience strong cyclonic storms (Mastronuzzi et al., 2006) and 'extraordinary' hurricane force winds of limited magnitude and an estimated frequency of $<1 \mathrm{a}^{-1}$ (Emanuel 2005, Fita et al., 2007, Moscatello et al., 2008). The latter generate extreme wave heights in the range of 5-7 m, although exceptional heights of 1011 have been reported from the western Mediterranean (Lionello et al., 2006). Longer term wave records are available from Catania, Sicily, from which a 50 year extreme wave height of up to $9 \mathrm{~m}$ is estimated (Schiccitano et al., 2007). In the qualified absence of major tropical storms and oceanic fetches, the central Mediterranean is a most useful test location.

This paper extends the initial findings of Mottershead et al., (2014), who present a broad review of both depositional and erosional evidence for extreme wave activity in the Maltese Islands, which impacted the northeast flank of the archipelago (Figure 1). Extreme wave signatures, both depositional and erosional, are widely distributed along the $\mathrm{NE}$ flank of the archipelago and are present up to elevations of $>20 \mathrm{~m}$ asl. Mottershead et al (2014) interpret these terrains as tsunamigenic in origin, based principally on sedimentary signatures comprising boulders, gravels and sands. Values of run-up inferred from depositional signatures provide a basis for retrodictive estimates of tsunami wave height according to the robust model of Synolakis $(1987,1991)$. Displaced boulders found onshore provide input data for the models of Nandasena et al., (2011), which permit retrodiction of shoreline tsunami wave height required for their detachment from source and subsequent transportation. These procedures independently produce similar values of shoreline minimum tsunami wave height ranging from 1.5-3.8 $\mathrm{m}$ from run-up, and in excess of $\sim 4 \mathrm{~m}$ from models of bedrock detachment, suggesting minimum shoreline tsunami wave height values locally of up to $\sim 4 \mathrm{~m}$. By contrast, the known storm wave climate is unable to explain the detachment of up to $30 \%$ of the larger boulders recorded (Mottershead et al., 2014). Preferred orientations of large imbricate boulders throughout the NE coasts of the Maltese Islands lie almost exclusively in the NE quadrant, clearly pointing to that quarter as the source of the flows which deposited them. 
The depositional signatures upon which the tsunamigenic interpretation is founded are accompanied by erosional forms which have also been interpreted as extreme wave signatures (Bryant 2001, 2014). The erosional forms presented in this paper include i) locations from which rock mass has been removed - specific features such as sockets in rock platforms, clifftop scars and eroded scarps, and ii) swept and scoured terrains and assemblages of erosion features that are difficult to explain other than resulting from widespread overwashing by a large and powerful flow or flows of water. The purpose of this paper is, therefore, to:-

- present a classification of extreme wave erosional features from the Maltese Islands;

- provide quantitative characterisations of these features;

- identify the geographical, topographic and associational patterns shown by these erosion features;

- interpret the commonality of conditions required for formation of these erosion forms in relation to potentially available extreme waves in the Mediterranean;

- demonstrate the extent to which study of erosional signatures may complement associated depositional signatures in developing a more fully informed perspective on any rocky coastline exposed to extreme wave events;

Our broader intention is to assess the extent to which erosional signatures of extreme waves such as those recognised by Bryant \& Young (1996) are present in the Mediterranean region, and to evaluate their interpretive potential.

\section{Field Area}

The Maltese islands are situated at a pivotal point in the central Mediterranean Sea, some $90 \mathrm{~km}$ south of Sicily and exposed to maritime influences, including tsunami and storm waves, extending from the Levantine coast to Gibraltar, and from southern Europe to North Africa. The perimeter of the Mediterranean imposes limits on the fetch of storm waves reaching Malta. Maximum fetches of $1900 \mathrm{~km}$ and $1200 \mathrm{~km}$ extend to the $E$ and NW respectively; most other fetches extend to $300-700 \mathrm{~km}$, with the exception of $\mathrm{N}$ where Sicily lies only $90 \mathrm{~km}$ distant (Mottershead et al., 2014; Table 1).

The effects on shoreline processes of cyclonic waves (Lionello et al., 2006) and Scicchitano (et al., 2007) are yet to be evaluated, and their implications for Malta are 
difficult to quantify at the present time. Drago et al., (2013) present wave records for Malta from 01.01.2007 onwards. Wave directional frequencies show that the greatest wave energy is derived from NW sextant with a minor peak in the NE sextant. The maximum storm wave height modelled for a 5 year period in proximity to NE Malta is $\sim 5.5 \mathrm{~m}$. The effects of wave reflection at a cliffed coast would raise the potential maximum wave crest level to $~ 5.5 \mathrm{~m}$ asl (Hansom et al., 2008).

Malta has a microtidal regime with oscillations of up $0.2 \mathrm{~m}$, although seiches with amplitude of up to $1 \mathrm{~m}$ also affect NE facing embayments (Drago 2008, 2009). Water depths typically vary between $3 \mathrm{~m}$ and $10 \mathrm{~m}$ along rocky Maltese shorelines and are deepest at rocky headlands such as Aћrax where a maximum of $20 \mathrm{~m}$ is recorded. The seabed slopes quite steeply on the NE coast with the $30 \mathrm{~m}$ submarine contour normally lying some 300-500 $\mathrm{m}$ from the shore (UK Hydrographic Office 2008).

To the $\mathrm{E}$ and NE, Maltese coasts are exposed to the consequences of seismic activity along the Calabrian arc and, in particular, the Western Hellenic arc. Maramai et al., (2014) catalogue known tsunami throughout the Mediterranean domain over the past 7000 years. A particularly strong tsunami event is known from 1630 BC caused by the explosion of Santorini, from which the ensuing tsunami stream was focused directly towards Malta (Kastens \& Cita 1981) and for which further sedimentary evidence is presented by Cita et al., (1996), Cita \& Aloisi (2000) and Polonia et al., (2013). Evidence for a further exceptionally powerful tsunami event in AD 365 from the Hellenic zone is described by Shaw et al., (2008) and Polonia et al., (2013).

The Maltese islands are composed mostly of limestones (Table 2), (Pedley 1978, Pedley et al., $1976 \mathrm{a}, 1976 \mathrm{~b}, 2002$ ). These form plateau landscapes and expose a range of coastal topographies to marine processes (Mottershead et al., 2014). The principal rock formations are the Upper Coralline Limestone and Globigerina Limestone of Miocene age and the Lower Coralline Limestone of Oligocene age. The coralline limestones are in general well jointed and thinly bedded with individual units commonly $0.5 \mathrm{~m}$ thick, and occasionally up to $1.5 \mathrm{~m}$. They are highly variable in compaction and mechanical strength. The Globigerina Limestone is more massive, with individual units from one to several metres thick, and characteristic compressive strength values of 15-30 MPa (Cassar et al., 2008, Cassar 2010). Basic rock mechanical properties are summarised in Table 3. 
Our field sites include linear coasts normal to the inferred approach of extreme waves, arcuate promontories with low platforms, and peninsulas with spatially complex three dimensional relief rising to $>20 \mathrm{~m}$ asl (Table 4). These various terrain types elicit contrasting responses from a wave advancing onshore as evidenced by depositional signatures (Mottershead et al., 2014, Mottershead et al., under review).

\section{Methods}

Reconnaissance surveys throughout the islands enabled the initial identification of the nature and distribution of the erosional signatures. An extensive approach was then applied to the principal sites, with observation of elevations and distances to shoreline and characteristics of the features. A small number of observations were made at subsidiary sites. The field site locations are shown Figure 1 and their topographic characteristics in Table 4.

Topographic mapping of the study sites was undertaken by field survey with a digital theodolite, supplemented by digital transformation of existing published DOS 1:2500 maps, with contours reinterpolated to a metric scale. At selected sites an intensive approach was adopted, embracing GPS survey and detailed observation of specific landforms. Geomorphic mapping was undertaken of defined specific geomorphic features with a combination of tape, Abney level and field photography; GPS was used in determining locations.

Field investigation was supplemented by analysis of remotely sensed imagery. Google Earth provided a perspective at site level, and images from 1:4000 aerial photography of 1967, 1993 and 2008 facilitated the observation of individual features using the Stereo Analyst function in ArcGIS 10, and subsequent mapping to ERDAS Imagine 10. Field and remotely measured features were plotted on to the transformed DOS 1:2500 maps.

\section{A Classification of Erosional Forms}


Landforms of coastal bedrock erosion can be broadly classified into forms created predominantly by forces of lift, shear and a combination of both lift and shearing. Although there is a degree of overlap between some categories, this grouping serves as a basic framework for the discussion of the observed features (Table 5). The geographical distribution of the observed erosion forms is listed by field site in Table 6 .

\section{Lift Forms}

\section{Sockets}

Sockets are here defined as cavities with near-vertical sides and a bedrock floor, inset into a roughly planar bedrock surface. In our field area they are commonly 1-5 m in lateral dimensions and up to $1.3 \mathrm{~m}$ deep. Such forms have been termed 'small' potholes by Bryant \& Young (1996).The term socket has also been used by Knight \& Burningham (2011), Hall et al., (2006, 2008), and Hansom et al., (2008) in referring to rock detachment scars irrespective of morphology.

Nott (1997) and Nandasena et al., (2011) model their formation as the removal by a simple vertical lift force of a mass of bedrock joint-bounded at its base and on all sides. A significant lift force is required to undertake such a task and in the coastal context such a force would be created by decompression following the passage of the peak of a large wave or flow. The lift force required, dependent on rock mass and density, is proportional to the vertical axis length of the rock mass and wave height as modelled by Nott (1997) and (Nandasena et al., 2011). Once created by the removal of what was, in effect, a keystone, the newly formed socket will expose freshly created scarps around its perimeter. Since the shearing force required to detach jointed blocks exposed on these marginal scarps will be less than the decompression force required for keystone extraction, the socket can then be readily enlarged by further flows across it. It is also possible that rock locally may be fragmented by prior weathering, and that incoherent weathered rock, may simply become entrained by turbulent flow of sufficient velocity.

We have observed sockets at six sites distributed across four locations spanning a range of elevations from sea level to $13 \mathrm{~m}$ asl (Table 6). They occur variously as isolated individuals, clusters and compound forms whereby separate depressions form multiple contiguous hollows in the socket floor, representing the amalgamation of adjacent hollows from which individual blocks have been removed. 
The characteristics of significant socket fields (clusters of sockets) are shown in Table 7. At Aћrax, socket fields are found on the exposed locations on the nose of the headland at 10-13 $\mathrm{m}$ asl, and the east side of the ridge from $\sim 4-\sim 7 \mathrm{~m}$ asl (Figure 2). These two locations are self-evidently directly exposed to the forces of any major assailing wave from the NE. Planform dimensions of sockets at Aћrax Head range from 2- $4 \mathrm{~m}$, with a maximum of $>6 \mathrm{~m}$, and depths range from 0.5-1.3 $\mathrm{m}$ (Table 8). Two smaller fields are present on the sheltered lee side of the Aћrax ridge, one along its flank at $\sim 7 \mathrm{~m}$ asl, and another on the valley floor at $\sim 6 \mathrm{~m}$ asl. Field evidence including orientations of displaced boulders and the relative distributions of erosion and deposition features suggests that a flow of water came through and over a col in the ridge, whilst another flow came up from the bay immediately west of Aћrax Head (Mottershead et al., 2014), to create a zone of turbulence in the confluence zone and conditions conducive to socket field development. The combined backwash of the two confluent flows would have created an enhanced backwash downvalley into the bay.

At White Tower site a socket field forms a belt some 9-45 $\mathrm{m}$ inland from the shoreline at an altitude of 3-5 $\mathrm{m}$ asl towards a steepening hillslope (Figure 3). At this point, an assailing wave would have flowed across rough rocky terrain and been increasingly retarded by the positive slope inflection. At Water Park site the socket field is adjacent to the shoreline at an altitude of $<1 \mathrm{~m}$ asl, on the NW north coast of a low promontory. It is directly exposed to wave action through a limited arc of $\sim 60^{\circ}$, from a northerly direction.

Formal sampling of a set of 43 sockets with long axis of at least $1.0 \mathrm{~m}$ developed in Upper Coralline Limestone, and excluding evidently compound forms, was undertaken at the White Tower site. Dimensions of the principal axes were observed, and shape indices, box volumes and extracted rock mass (incorporating rock density) were then calculated, as summarised in Table 8. Boxplots of long and short axis measurements are shown in Figure 4. Of particular note is the narrow range of the $c$-axis observations with $70 \%$ lying in the range $0.5-0.7, \mathrm{~m}$ apparently indicative of the control of bedding plane spacing on socket depth. A small sample of sockets $(n=12)$ developed in Lower Coralline limestone at Water Park site yielded slightly larger volumes, but similar geometries.

Socket fields are thus present in landscapes formed of both Lower and Upper Coralline

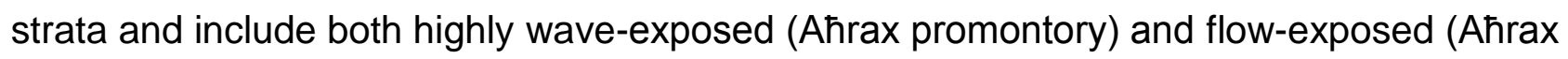
bay) environments. In altitude their locations range from $<1 \mathrm{~m}$ to $>13 \mathrm{~m}$ asl. Of particular 
significance is their abundance in exposed sites at $>10 \mathrm{~m}$ asl and up to $60 \mathrm{~m}$ from shoreline at Aћrax Point, consistent with substantial flows of water across landscapes of varied relief (Mottershead et al., 2014).

There is no known record of storm waves reaching, or even threatening, the more elevated locations inland. The facts that Aћrax summit at $14 \mathrm{~m}$ asl was chosen as the location of an $80 \mathrm{~m}$ high wind recording mast (Figure 2), and that there are permanent structures at $6 \mathrm{~m}$ asl in the nearby valley, imply that these locations are not felt to be threatened by storm waves. This strongly suggests that although it is entirely possible that the sockets on contemporary shore platforms may have been formed under current storm conditions, those at Aћrax Head, by virtue of their elevations and distances landward, were formed by a wholly exceptional extreme flow or flows. Further quantitative testing of this assertion is undertaken later in this paper.

\section{Megasockets}

Uncommonly large socket forms are present on coastal ramps formed in the Upper Coralline beds on both the south and north coasts of Comino up to $10 \mathrm{~m}$ asl. Their planform is clearly visible on Google Earth imagery and demonstrates a clear association with bedding-normal linear fissures in bedrock, the majority of which trend approximately normal to the shoreline, although some align parallel to it. In some places the fissures open out to form a conical or cylindrical hollow; in other cases a lateral widening occurs at an intersection of bedding-normal fissures. They exhibit planform dimensions of up to 11 $\mathrm{m}$ by $6 \mathrm{~m}$ and range in depth up to $2.5 \mathrm{~m}$ (Figure 5).

Some of these megasockets have a depth approximately equal to the thickness of the surface rock stratum in which they are formed and possess a visibly solid floor, and may be interpreted as formed through block extraction by decompression. Others are formed in more thinly bedded and less coherent limestone units, and contain rubble of mixed cobbles. While this could suggest that their parent rock was weathered into incoherence prior to multiple shallow boulder extractions, it could also be that the megasockets have simply acted as sediment traps since their formation. Although secondary scour processes may have modified these sockets their predominantly angular internal morphologies are more suggestive of block detachment rather than abrasion as the formative mechanism. 


\section{Lift plus shear forms}

\section{Clifftop detachment scars}

A clifftop detachment scar is a joint-bounded step-like scar formed at a clifftop by the detachment and erosion of a block or slab of rock. The process of detachment of such rock masses is documented by Hall et al., (2006), Hansom et al., (2008), Etienne \& Paris (2010), Pignatelli et al., (2010), Paris et al., (2011), and Engel \& May (2012). It requires incoming waves large enough to overtop a cliff, exert a lift force against the coastal underside of any clifftop overhang and/or apply a shearing force against a clifftop face, tending to prise the rock upwards and carry it forward over the lip of the cliff and inland.

At Aћrax Head a clifftop scar measuring $15 \mathrm{~m}$ long, $5 \mathrm{~m}$ wide, up to $1.5 \mathrm{~m}$ deep (Figure 6a, b), and trapezoidal in planform, is formed atop a sea cliff some $10 \mathrm{~m}$ high. Nearby, a large isolated boulder ( 60 tonnes), lies some $12 \mathrm{~m}$ inland from the clifftop scar. This boulder is tabular in shape, and measures $6.60 \times 2.75 \times 1.37 \mathrm{~m}$ in axial dimensions. It is riven into three contiguous fragments, which now lie immediately adjacent to each other at the point of deposition. The boulder is located close to the crest of a ridge; there are no river channels adjacent, nor any significant overlying slope which could have delivered it by mass movement processes. In the noted absence of slopes and other erosional agents, the only large scale powerful agent available locally for transportation is that of the sea, $>10 \mathrm{~m}$ below.

The clifftop scar, of similar lithology and depth to the boulder, is thus interpreted as the source of the boulder. Conceivably, the wave responsible was large enough to overtop a clifftop at $\sim 10 \mathrm{~m}$ asl with an overflow sufficient to lift and detach the boulder, drive it onshore for a distance of $15 \mathrm{~m}$ and deposit it nearby with such force that it shattered into three major fragments.

\section{Eroded Scarps}

Strongly bedded Upper and Lower Coralline limestones are the most abundant rock types at the study sites, where they commonly dip gently seaward forming sloping shore platforms (Xghajra, Żonqor) and coastal ramps (Quarry, Qorrot). Extraction of blocks of 
rock, joint- bounded on 2 to 4 sides including the subjacent bedding plane, the parent scarp face plus 1 or 2 laterally bounding joints normal to the dip, then produces linear scarps up to $100 \mathrm{~m}$ long and $2.5 \mathrm{~m}$ high according to local bedding and topography.

Eroded scarps at the Maltese coastal sites are somewhat unusual in that they are distinctively clean and lacking significant the talus that would normally accumulate at a subaerial scarp foot. Whilst some such scarps occur at low elevations and are swept by storm waves, others lie at substantial distances inland and altitudes above sea level.

The processes by which rock becomes eroded would appear to be strongly influenced by lithology. In many locations, such as Qorrot and Żonqor, erosion occurs in the form of detachment of a jointed rock mass where a flow of water applies a shear force as it overrides the face of a rock mass, rotating it upwards and allowing water underneath the rock to apply a lift force. This causes a boulder to become detached and move away from its seating, exposing the faces of former rock joints (Hansom et al., 2008, Engel \& May 2012). In contrast, other locations such as Aћrax Head show rounded and irregular rock surfaces, indicative of scouring by abrasion forces applied by a swirling mass of water, which may have subsequently modified a newly exposed detachment scar surface.

At Qorrot, the resistant Phosphorite Conglomerate Bed (PCB) (Pedley et al., 1976a) forms a very distinctive scarp at an altitude of 7.5-8 $\mathrm{m}$ asl within the Globigerina Limestone. Some $0.5 \mathrm{~m}$ high, it is undercut at the basal contact with the underlying limestone. The flow-normal scarp orientation ensured that jointed tabular rock masses were broken off the scarp face and swept onshore. Several slabs lie arrested in various poses against the scarp front, others now sit atop the scarp and overlying slopes at elevations of up to 12.5 $\mathrm{m}$ asl. This distinctive lithology acts as a tracer and clearly reveals loci of boulder detachment, deposition and vector of travel.

On the exposed nose of Aћrax Head are two major scarps some 2 to $3 \mathrm{~m}$ high lying at $\sim 8$ $\mathrm{m}$ asl and $\sim 10 \mathrm{~m}$ asl respectively (Figures $2,7 \mathrm{a}$ ). Their alignment runs NE to SW (flowparallel), and they are noteworthy for an absence of scarp foot clastic material. The lower scarp face has a morphology in which differential erosion has picked out the internal structures of the rock in relief; it is also associated with streamlined pinnacle and fin outlier forms. Together these suggest that scouring and abrasion have played a part in sculpting them, indicative of a flow bearing a significant concentration of abrasive particulate 
sediment. The flow-parallel orientation would in any case have facilitated the sweeping away of any eroded rock debris laterally downslope into the adjacent bay where boulders lie distributed in the sublittoral zone (Figure 2).

At Qorrot the detachment of scarp face boulders at altitudes of 7-8 $\mathrm{m}$ asl and their upshore transportation to $12.5 \mathrm{~m}$ asl up a terminal slope of $25^{\circ}$ would require a flow of water to reach at least this elevation and extend $>70 \mathrm{~m}$ inland from the shoreline. The altitude and magnitude of the scarp features at Aћrax require a substantial flow of water at up to $>12 \mathrm{~m}$ asl, a requirement consistent with the presence of adjacent imbricate boulders. At both sites the eroded scarps and their context thus strongly suggest a powerful flow of water at altitudes beyond the reach of regular storm waves. Scarp erosion (by detachment of jointbound rock masses) leads to scarp retreat, thus revealing a freshly exposed bedding plane, a smooth rock surface often extending over hundreds of square metres clearly indicates that scarp forming rock has been removed to form stripped terrain (Figure 7b).

\section{Shear Forms}

\section{Scoured terrain}

We use this term to describe terrains lacking soil and regolith and exposing a bedrock surface which shows clear evidence of incision by erosional forms. Terrain forms which fit this category have been described by Bryant \& Young (1996) and Bryant (2014).

These scoured terrains commonly exhibit bare rock surfaces with a relative relief of $0.5-1.0$ $\mathrm{m}$, and occasionally higher. Frequently the spatial pattern of relief has no discernible regularity, in some areas lacking forms of relief that can be meaningfully codified, measured, or named. In other places, however, recognisable forms are present and spatial patterns may be discerned as follows:

- mammilated terrain, with hummocks $\sim 1 \mathrm{~m}$ height

- isolated rounded or fin-like bedrock pinnacles up to $1 \mathrm{~m}$ high standing as erosional remnants

- a slope surface formed of irregular basins interconnected by chutes, a terrain type termed as cascade by Bryant \& Young (1996), although those authors use the term at the macro rather than micro landform scale. 
- rocky runnels and gullies up to $2 \mathrm{~m}$ deep incised along joint planes, forming a rectilinear pattern oblique to the overall gradient of the local terrain (Figure 8).

Such chaotic bare rock terrains are present on the exposed promontories of Aћrax and Ghemieri, and at the eastern headland bounding San Niklau (Figure 1). At Aћrax and Ghemieri sites they are found at elevations of up to $\sim 11 \mathrm{~m}$ asl and up to $40-70 \mathrm{~m}$ from the shoreline. At San they are found from $12 \mathrm{~m}$ asl down to the shoreline some $70 \mathrm{~m}$ distant and are dissected by several bedrock gullies up to $30 \mathrm{~m}$ long.

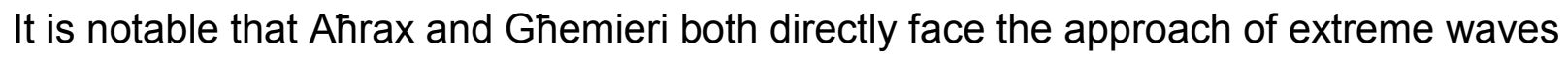
from the NE, the inferred direction of approach of a major extreme event or events (Mottershead et al., 2014). At these sites field evidence shows that the assailing flow passed up and over the headland, and through a col in each case, at altitudes of 7.3 and 5 $m$ asl respectively, completely overwashing the peninsulas and draining into embayments landward of the cols with negligible backwash. In contrast, on slopes directly facing the wave approach, the backwash would have drained back as return flow whence it came. At the San Niklau site, sedimentary evidence indicates that the coastal flank of N Comino was overwashed laterally at an elevation of some $12 \mathrm{~m}$ by an encroaching wave travelling from the NE along the North Comino Channel. The overtopping bore would then have been accelerated by gravity as it flowed off down the promontory westwards to drain into San Niklau Bay.

Notable morphological characteristics of the scoured terrains are:

- they display both areally eroded terrains and linear elements;

- there is a notable lack of a catchment area above the incised terrains;

- the alignment of the gullies does not necessarily coincide with the fall line of the slope;

- they may lack any coherent and integrated drainage channel network;

- there is evidence in some forms (e.g., mammilated terrain, gullies) of structural control exerted by lithological variations and joints;

- there is a notable absence of sediment representing the eroded material which, apart from the occasional isolated clast lodged in a gully, has evidently been removed from the site (e.g., scoured gully across Ghemieri headland, cf. Figure 6 of Nott \& Bryant, 2003); 
The characteristics of the terrain surfaces suggest that the process that formed them was predominantly an areal rather than a linear process, though some linear elements are present where significant rock joints are evident (Figure 8). The scoured terrains lack an organised drainage pattern which experience and theory suggest would develop in a landscape over time. The associated chaotic pattern suggests a short lived, high energy, catastrophic event in the form of a high velocity flow or flows washing over the landscape.

\section{Spillways}

A spillway is defined as an overflow of water through a topographic low point. In a coastal context this can occur within either an indentation in the planform of the coastline itself, such as a ravine or narrow embayment, or a col through a ridge parallel to the coastline. When an incoming assailing wave enters a closed canyon, its flow becomes concentrated into an increasingly narrow cross section and at the canyon apex may begin to overflow a terminal cliff. Where a ravine terminates in an enclosing cave, the trapped wave may weaken or rupture the cave roof causing it to collapse. Following the collapse a spillway may form at the head of the ravine.

Ahrax peninsula shows a case of an onshore flow passing over a transverse ridge to create a complex pattern of flow overwashing the landscape (Figure 2 and Mottershead et al., 2014). The consequences of this in terms of erosion processes and the distribution of some erosional forms (sockets and scarps) were described earlier.

Ghemieri peninsula offers an example of a spillway at the head of a ravine (Figure 9). On the $E$ side of the col is a ravine open to the NE, some $60 \mathrm{~m}$ long and narrowing landwards from $30 \mathrm{~m}$ to $5 \mathrm{~m}$, flanked by vertical cliffs decreasing in height from $7 \mathrm{~m}$ at its seaward entrance to $5 \mathrm{~m}$ at its head. A stack of imbricated large tabular boulders with a maximum a-axis of $3.8 \mathrm{~m}, \mathrm{c}$-axes up to $1.2 \mathrm{~m}$, and ranging in volume up to $20 \mathrm{~m}^{3}$ forms a ramp extending up from sea level to the headwall crest (Figure 10a). The uniformity in size and shape suggests that they represent remnants of a large formerly coherent sheet of rock and have undergone minimal transportation following their initial fragmentation. This is consistent with the presence of a coarse grained massive Upper Coralline bed $>1 \mathrm{~m}$ thick now forming the caprock of the flanking cliffs of the ravine. 
The simplest interpretation of these is that they are remnants of a former cave roof, fractured and loosened, perhaps by a major impact consistent with extreme wave attack, which collapsed under gravity into the surging waters below. They are now clearly in a position inconsistent with a simple vertical plunge, and lie swept up to the ravine head to be trapped against the terminal cliff their current imbricate configuration. They now form a ramp facilitating smaller boulders to saltate up and over the headwall cliff.

Aligned with the head of the ravine, and some $9 \mathrm{~m}$ landward of its lip, lies an erosion scar at some $5 \mathrm{~m}$ asl. It is crescentic in planform and, measuring some $20 \mathrm{~m}$ in both width and length, and is incised up to $3 \mathrm{~m}$ into surface bedrock (Figure 10b). Above the erosion scar, the bedrock beyond its headcut has a smooth surface linking it to the lip of the ravine. The planform of the scar is convex upstream and within it lie tabular bedrock boulders up to 2 $m$ in length and similar in form to the imbricates trapped in the ravine. In the adjacent Santa Marija Bay, aligned with the head of the ravine and the erosion scar, lies a sublittoral fan of large boulders, up to 10 tonnes in mass (Figure 9).

This set of features is interpreted as a spillway created by an extreme wave or waves driven into the closed ravine from the NE that were funnelled to the apex to create a sluicing high velocity flow that scoured out the plunge pool, before flowing on into Santa Marija Bay. It thus represents a local topographic perturbation of a high energy flow.

\section{Swept rock terrains:}

We use this term to describe smooth coastal bedrock slopes that are characteristically swept clear of soil and regolith, although they may bear soils occupying sheltered cavities and/or some isolated boulders and remnants of sediments (Figure 11). By definition (in contrast to scoured terrain) they lack significant evidence of incision and (in contrast to stripped terrain) are not associated with an adjacent scarp. The defining characteristic is the absence or scarcity of surficial clastic material. This may be emphasised by the presence of a boulder or megaclast berm at the upper margin of the swept zone, the clasts then fining upslope over a distance of 20 metres or more (cf. Figure 2 in Nott \& Bryant 2003). Such terrains are identified by Bryant (2014: p.55) and Pignatelli et al., (2010) as indicative of overwashing of coastal slopes by high velocity flows.

These terrains are well exemplified at Quarry, Qorrot and Ghemieri sites, where a bedrock ramp forms a slope extending upwards from a low shoreline cliff over distances of up to 60 $\mathrm{m}$ and elevations of up to 7-12 $\mathrm{m}$ asl (11). At Żonqor, a zone of swept terrains extends for 
$>600 \mathrm{~m}$ along the coastal slope. It lies at a distance of 70-100 m inland from the present shoreline, at altitudes ranging from 10-18 $\mathrm{m}$ asl, well above the reach of contemporary storm waves as indicated by the lower limit of enclosed land which extends down to $\sim 11 \mathrm{~m}$ asl. The zone is characterised by smooth swept intermittent rock exposures with a slightly patinated weathered surface, separated by a sward of grasses and shrubs in thin soils.

Such forms are present on all major limestone formations in this study, including Upper Coralline (Ghemieri, South Mellieћa Bay), Globigerina (Qorrot, Żonqor) and Lower Coralline (Quarry) sites. The swept surface is interpreted as representing a zone where the onshore flow velocity was great enough to entrain and remove all or most of the clastic material available, but insufficient to erode bedrock by incision. This combination of features is indicative a large wave encroaching onshore and upslope until its energy became spent.

\section{Discussion}

\section{Distribution of Erosion Forms}

The frequency of erosion forms across the study sites is shown in Table 6, whilst Figure 12 plots their distribution in relation to elevation and lithology. The following observations arise:

1. At all sites the erosion features lie at lower elevations than the highest depositional feature;

2. The altitude of the erosion features varies significantly between sites, reflecting exposure, topography and local runup power;

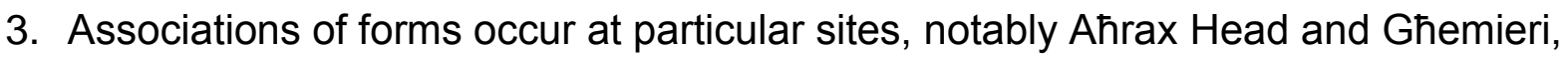
implying a commonality of conditions under which they collectively formed;

4. The altitude of sockets and erosion scarps spans a range from sea level up to $13 \mathrm{~m}$ asl, implying a single causative agency operative throughout that entire range;

5. The range and frequency of erosion forms is higher on the Upper Coralline Limestone (16 occurrences on 5 sites) than on Lower Coralline beds ( 5 on 3 ) and Globigerina (4 on 2 ), implying significant lithological control;

6. Scarp erosion necessarily depends on exposures of well bedded scarp-forming strata;

7. cliff top scars and spillways require the prior existence of appropriate topographies. 
A closer perspective on distributions is provided by individual sites, which integrate the spatial relationships between erosional and depositional features.

\section{Controls on erosion by extreme waves}

The development of the erosional forms is a function of the assailing force of the wave(s) and the resistance of the rock. The assailing force depends on the size and type of waves, the exposure of the coast, its topography and orientation in relation to the assailing wave. The resistance to erosion depends on the lithology, principally rock hardness, bedding and jointing characteristics.

Topography: Local topography will either (i) concentrate waves on headlands by refraction (ii) deflect an uprush of water up a cliff face, (iii) allow overwashing of low cliffs, (iv) form a sloping runup surface (Quarry, Qorrot, Żonqor), (v) funnel a flow through a col

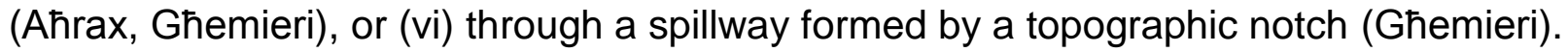
Topography can concentrate flows in such areas or dissipate them on steeper, longer and rougher slopes or within sheltered embayments.

A general decrease in velocity can be expected with increasing positive gradient and distance inland up to the runup limit. Where the overwashing water flows downhill, then velocity increases, as during return flow following maximum runup, or as part of the overwashing process where the assailing wave encounters a negative gradient as at Ghemieri, San Niklau and the lee side of Aћrax col, where the driving force of the water mass is augmented by gravitational acceleration. The constricting effect of a spillway, and especially a restrictive topographic notch, would have a local effect enhancing run-up and flow depth. Thus, the distribution of erosional stresses exerted by the overwashing flow will vary according to local topographies.

It is evident that the erosion forms described above are the products of differing levels of applied force. The lifting and excavation of slabs of rock to form sockets, and the lifting and shearing of rock masses from a scarp front quite evidently require the application of higher levels of force than scoured terrains and swept terrains that simply require transport of rock debris and/or soil across a ramp. The resulting patterns in the landscape created by the interaction of topography and the forces applied by an overwashing flow are illustrated in Figures 2 and 9. 
Flow intensity/magnitudes: We argue intuitively that there is a gradation of flow intensity overwashing the landscape which can be related to the formation of identifiable erosional forms in rock (Table 5). Their presence, absence and distribution can be regarded as a function of the variable nature of the overwashing flow and local bedrock properties. Clearly some features require significantly higher forces and flow energies for their creation than others, along a continuum of decreasing flow intensity. A schematic model of the possible relationship between variation in flow intensity and the associated landforms is presented in Figure 13. The forms observed are plotted against a subjective scale of flow intensity to display the range of energy levels and associated dominant processes likely to be responsible for their creation.

Based on hydrodynamic considerations (Nott 2003, Nandasena et al., 2011 and others) it is evident that decompression effects to cause socket creation require the highest flow intensity. Forces of medium intensity create shear stresses through hydraulic impact sufficient for bedrock erosion via mechanisms of detachment from scarps. However, with diminishing flow a threshold is reached at which rock mass detachment no longer takes place, and flowing water (including any entrained debris) simply acts as an abrasive agent. At low levels of intensity, the hydraulic forces are sufficient only to remove material already in clastic form, leading to swept platforms.

At lower velocities again lies the realm of deposition, with sediments successively fining as velocity diminishes further. This is observed at Quarry site in particular, where the boulder berm marks the transition between erosional and depositional domains. In this way we can link the comparative flow intensities required for rock erosion to those with a sweeping effect on the landsurface, and those causing deposition. If these associations are accepted then it is clear that the study of erosion forms can yield significantly greater insights than the study of depositional evidence (e.g. boulders) alone.

Lithology: At the broader level the influence of lithological control is apparent. The three main formations show distinct differences in frequency and range of forms present, with the highly variable Upper Coralline Limestone the most susceptible to extreme wave erosion and the harder, more massive Lower Coralline Limestone the least (Tables $2 \& 3$ ). At the local field scale, the differential erosion manifest in gully incision along joint planes 
on scoured terrain and the development of mammilated terrain and the haut-relief of bioforms are also indicative of lithological control.

Jointing appears to be particularly relevant in determining whether rock is more likely to yield small detritus by abrasion or be lifted as discrete masses from rock surfaces as boulders. The thickness of the more competent beds within the Maltese limestones appears to act as a ubiquitous control on boulder size, as described by Stephenson \& Naylor (2011) with respect to contemporary erosion in South Wales, UK. Bed thickness commonly determines the $c$-axis dimension, a major control on whether a boulder is susceptible to detachment by decompression. Joints normal to the bedding planes then act as a further control on boulder size in relation to wave entrainment capacity. Thus the well defined bedding and jointing of competent rock units within the Upper Coralline define rock masses susceptible to wave erosion by socket creation and scarp erosion. The Lower Coralline beds are thicker with less frequent bedding plane joints, and so less amenable to the release, lifting and extraction of blocks. Within the Globigerina beds, only the Phosphorite Conglomerate commonly has a close enough joint spacing to fracture into blocks commonly falling within the competence of extreme wave transport. The main Globigerina Limestone releases detached blocks with $a$-and $b$-axis lengths measured in metres and $c$-axis commonly $\sim 1.5 \mathrm{~m}$. The largest apparently detached but unmoved clast measures $10.3 \times 4.3 \times 1.5 \mathrm{~m}$ with a mass of $\sim 160 \mathrm{t}$. Removal from its socket would appear to lie beyond the competence of current and recent storm wave processes, and it appears to define a minimum limit for clast stability under contemporary storm wave conditions.

\section{Retrodiction of waves required to create selected erosional forms (sockets and clifftop scars):}

Quantitative models have been widely used to retrodict the types of wave responsible for historic extreme wave features, particularly in attempting to differentiate between the erosional capabilities of storm waves and tsunami. Such models are more applicable to transported clastic material, i.e. boulders, because the absence of the removed material from erosional sites generally makes it difficult to quantify the mass of the now removed clasts, or their initial configuration. Hence the kind of information required to satisfy such models is generally absent from most types of erosional feature. With appropriate assumptions and caveats, however, two erosional forms, sockets and detachment scars, do offer the possibility of such modelling. 
In the case of sockets, the working assumption is that they represent casts of the removed boulders. The socket form thus offers a means of estimating the size of wave which initiated it. Some sockets may have been enlarged subsequent to their initial formation, but with the thinly bedded limestone of Malta such enlargement is more likely to be lateral rather than vertical. Socket observations indicate that $c$-axis depths are controlled strongly by the thickness of the competent strata in which the socket is formed and typically are within the range $0.5 \mathrm{~m}$ to $1.5 \mathrm{~m}$. Since lifting of rock is dependent on only one of the principal axes of the boulder, the $c$-axis representing the depth of the socket (Nandasena et al., 2011), the assumption that the socket depth represents a single vertical extraction is important. For that reason megasockets that may have a compound origin are not included in this analysis. When identifiable detached material lies nearby, detachment scars are also susceptible to modelling with appropriate equations.

Assuming a socket to be formed by a single extraction event the formative wave height required at the socket site, whether storm or tsunami, can be modelled with equations developed from Nott (2003) and Nandasena et al., (2011; Eqn. 20) as follows:-

$$
\begin{array}{ll}
\left.H_{t} \geq 0.25 c\left[\rho_{s} / \rho_{w}-1\right)\right]\left[\cos \theta+\mu_{s} \sin \theta\right] C^{-1} & \text { Equation 1 } \\
H_{s} \geq c\left[\left(\rho_{s} / \rho_{w}-1\right)\right]\left[\cos \theta+\mu_{s} \sin \theta\right] C_{\mid}^{-1} & \text { Equation 2 }
\end{array}
$$

Where $\quad \mathrm{H}_{\mathrm{t}} \quad=$ tsunami wave height $(\mathrm{m})$

$\mathrm{H}_{\mathrm{s}} \quad=$ storm wave height $(\mathrm{m})$

$\mathrm{C}_{\mathrm{I}} \quad$ = coefficient of lift (typically 0.178 )

$\rho_{\mathrm{s}} \quad=$ density of boulder (mean values of $\mathrm{UCL}=2.28, \mathrm{LCL}=2.54$

(Table 3)

$\rho_{\mathrm{w}} \quad=$ density of seawater (1.025)

$\mu_{\mathrm{s}} \quad=$ coefficient of static friction (estimated at 0.7 )

$\mathrm{c} \quad=c$-axis length, assumed as socket depth

$\theta \quad=$ slope gradient, assumed as zero.

These were applied to socket data from the Aћrax (three sites), White Tower and Water Park headlands. Representative values of respective storm and tsunami wave heights required are shown in Table 9. 
Results show that the deepest sockets would require storm wave heights of between 4.8 and $8.9 \mathrm{~m}$. Furthermore, at all sites except Water Park such waves would need to reach the socket sites elevated at up to $13 \mathrm{~m}$ above sea level and up to $140 \mathrm{~m}$ inland. Given a maximum storm wave height of $\sim 5.5 \mathrm{~m}$ (Drago 2013) it would not be realistic for such storm waves to attain such altitudes. Thus, at each site there are sockets whose creation is beyond the known capacities of storm waves. However, a tsunami wave of feasible height at shoreline may readily be capable of running up the long, inclined and rough slopes to deliver a wave or bore of 1.20-2.23 $\mathrm{m}$ in height at the socket sites. The passage of such a wave or flow would also be consistent with the pattern of extreme wave deposits across the Aћrax ridge described by Mottershead et al., (2014). Although this analysis points to the likelihood of energetic tsunami run-up as a formative event for the largest, highest and most landward sockets, it also suggests that small to mid-sized sockets located close to the shoreline can also be created and modified by storm waves.

When identifiable detached material lies nearby, detachment scars are also susceptible to modelling with appropriate equations. Hansom et al., (2008) present models of extreme wave erosion from a clifftop scar. A model of joint-bounded detachment from a cliff top scarp (e.g. Figures 6a, b) driven by a "green water" bore that overtops the cliff top was considered the most applicable to the clifftop scar at Aћrax and the associated triple fractured boulder lying some $15 \mathrm{~m}$ inland at $10.4 \mathrm{~m}$ asl (Figure 2). By reassembling the three contiguous fragments the original single boulder is measured at $6.6 \mathrm{~m}$ long, with means of $2.75 \mathrm{~m}$ in width and $1.37 \mathrm{~m}$ in depth. The model predicts the velocity of a clifftop bore required to detach a clifftop boulder of specified dimensions.

$$
v \geq \sqrt{\frac{\mu\left(\rho_{s-} \rho_{w}\right)(a b c) g}{0.2 \rho_{w} a_{e} c C_{D}}} \quad \text { Equation } 3
$$

where:

$\begin{array}{ll}\mathrm{v} & =\text { velocity } \\ \mathrm{a}, \mathrm{b}, \mathrm{c} & =\text { boulder axes } \\ \rho_{\mathrm{s}} & =\text { rock density } \\ \rho_{\mathrm{w}} & =\text { water density } \\ \mathrm{C}_{d} & =\text { coefficient of drag } \\ \mathrm{g} & =\text { gravitational acceleration } \\ \mu & =\text { coefficient of friction }\end{array}$


Using the conservative assumption of a flow-normal long axis, a velocity value of $\geq 13.01 \mathrm{~m}$ $\mathrm{s}^{-1}$ was obtained. This can be used to retrodict the height of wave required, whether of storm or tsunami origin, at the point of detachment.

Velocity is related to bore height $\left(\mathrm{H}_{\mathrm{b}}\right)$ by: $\quad \mathrm{H}_{\mathrm{b}}=\frac{v^{2}}{g}$.

The estimated velocity translates into a bore depth of $\geq 17.3 \mathrm{~m}$ at the detachment elevation of $10 \mathrm{~m}$ asl, implying a bore crest at $\geq 27 \mathrm{~m}$ asl. It would appear unrealistic to suggest that this could be attained with a maximum extreme storm wave modelled in NE Maltese seas cresting at only $\sim 5.5 \mathrm{~m}$ asl.

The same power could, however, be attained by a tsunami wave of $\geq 4.3 \mathrm{~m}$ at the detachment point at $10 \mathrm{~m}$ asl. A bore crest at $\geq 14.3 \mathrm{~m}$ asl would not appear inconsistent with the presence of boulders and other sediments locally up to $>20 \mathrm{~m}$ asl which have been interpreted as tsunamigenic in origin (Mottershead et al., 2014). This would appear reasonably indicative of the magnitude of event required to detach the boulder and transport it to its current position, thereby enlarging the clifftop scar.

\section{Storm or tsunami waves?}

This issue can be approached by considering extreme wave signatures on the basis of both topographic data and modelling results.

Mottershead et al. (2014) presented evidence, indicated by imbricate boulder orientations, of an extreme wave flow impacting the NE coasts of the Maltese islands. The spatial organisation of high energy sedimentary deposits, their relationship to topographic features and their elevation of up to $>20 \mathrm{~m}$ asl on the Aћrax peninsula were interpreted as demonstrating beyond reasonable doubt that Maltese coasts had suffered major overwashing, of greater magnitude than extreme storm waves alone could reasonably achieve. Figure 2 summarises some of this evidence.

The evidence of the Ghemieri col here provides further topographic evidence in support of overwashing by a flow of extreme magnitude. The sequence of aligned features, boulder ramp $\rightarrow$ ravine head spillway $\rightarrow$ plunge pool $\rightarrow$ boulder fan interpreted earlier as a spillway route can now be interpreted in the wider context of the Ghemieri col.

The cross section of Ghemieri col (Figure 14) shows the topographic location of the spillway route in relation to various levels of potential overwashing flow. The maximum 
storm wave of $\sim 5.5 \mathrm{~m}$ would exceed the elevation of the lowest section of sea cliff facing waves from the NE. It is likely that it would marginally overtop the lowest point of the col at $\sim 4.5$ to $5 \mathrm{~m}$ asl and, faced with an unconstrained egress westwards, would simply drain under gravity flow into Santa Marija Bay beyond.

Sedimentary evidence, however, in the form of imbricate boulders indicates that the northern summit of the col at $11.5 \mathrm{~m}$ was significantly overwashed, and further boulder evidence on the southern slope implies that overwashing reached a minimum level of $17 \mathrm{~m}$ there. Thus it appears that Ghemieri col may have experienced a flow of water some 300 $\mathrm{m}$ wide and over $12 \mathrm{~m}$ deep. In relation to that scenario, it appears most likely that the event which generated such an extreme flow would also be responsible for the spillway forms, which simply represent a subsidiary thread of high velocity flow perturbed at the ravine head at the base of a much greater flow.

The evidence of large boulders deposited locally at elevations up to $>11 \mathrm{~m}$ asl implies that the flow was at least 6 metres deep at the head of the ravine, and deeper in the centre of the col and up the southern slope. The power of the flow event is further indicated by a shore-normal train of imbricate boulders with a-axes up to $>3 \mathrm{~m}$, deposited at altitudes of 6-7 $\mathrm{m}$ asl within the col some 30-50 m inland from a six metre high vertical sea cliff (Figure 15). Such an event is far in excess of any flow though the col feasibly created by storm waves as described above.

Indicative modelling of socket formation and cliftop scar development enable wave height retrodictions at the sites of erosion. In both cases storm waves of unfeasible dimensions would be required at the altitudes of the erosion sites concerned. In both cases tsunami waves of reasonable proportions would suffice.

We have presented evidence of a series of high energy erosion forms that are difficult to explain using the known storm wave climate of the NE Maltese sector. Difficulties relate to the magnitudes of some of the individual features and the elevations and distances seaward at which they have been formed. Both topographic and modelling considerations point to erosional features within Maltese coastal landscapes which cannot realistically be originated by storm waves alone but can, however, reasonably support a tsunamigenic interpretation. 
Interrelationships between erosional and depositional forms: Evidence from erosion and deposition features can be integrated to enhance interpretation of the formative

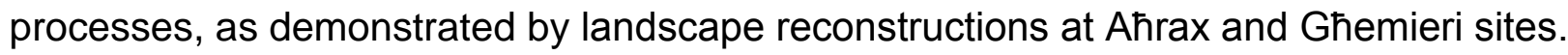

At Aћrax, a cliffed promontory exhibits a distinct col (spillway) at its neck, and cliffs rising steadily toward the south (Figure 2). Sockets are distributed within a belt 0-30 $\mathrm{m}$ from the $\mathrm{E}$ facing clifftop and erosion scarps are concentrated around the $\mathrm{N}$ and NW facing headland crest. The spillway displays shallow sockets within its central axis sloping towards Aћrax Bay. Boulders are distributed within a spread further inland at $30-110 \mathrm{~m}$ from the clifftop southwards up to $22 \mathrm{~m}$ elevation. Within Aћrax Bay a second zone of boulder accumulation is located to the SW of the headland, including submerged boulders. In each case, the preferred boulder orientations and the vector joining the respective locations of erosion features (source) and deposition features (sink) clearly indicate the directions of flow (Figure 2). The interpretation is that extreme wave impact from the NE on the headland and sea cliffs generated high velocity flows several metres deep, causing detachments of boulders from the clifftops and transporting them SW up the southern col flank. Flow energy rapidly diminished onshore, reducing its erosive capacity and creating a transition to the deposition of boulders at 25-35 m inland, grading into cobbles and gravel fining into sand deposition at 100-150 m inland. The lack of distinct accumulation berms appears indicative of a low frequency rather than repetitive event. At the nose of the headland, run-up significantly overtopped the crest to create deep sockets, whilst waves diffracted and refracted over and around the headland into the adjoining bay, flowing southward obliquely along its western margin. It is postulated that this excavated the distinctive erosion scarps at that location and deposited the detached boulders within the bay.

Ghemieri also presents a headland and col (spillway) morphology (Figures 9, 14). High energy erosion forms comprising sockets and stripped terrain have formed on the col floor immediately landward of low sea cliffs. Abraded and swept terrains are found further landward and at higher elevations up to $12 \mathrm{~m}$. Boulders on land are largely restricted to the southern margin of the col floor (Figure 9) but are complemented by a submerged fan extending into Santa Marija Bay (Houston, 2014). Boulder imbrications and a-axes consistently orient ENE - WSW. Collectively, these features are aligned from east to west in a sequence of diminishing energy with a transition from erosion to deposition some 30 $m$ landward of the sea cliff (Figures 9, 15). We contend that this represents a flow that 
transgressed the peninsula from the east. The magnitude of the flow is indicated by: (i) the distances and elevations of the landscape that were transgressed, and (ii) the initial estimate of around 3,000 $\mathrm{m}^{3}$ of translocated rock. The poorly organised and chaotic nature of the deposits across the peninsula again points to their formation by a low frequency rather than a repetitive event.

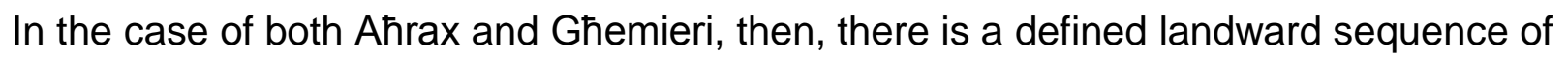
features of diminishing energy. At Aћrax, with its more varied topography, a more varied pattern/distribution of events is portrayed; in both cases, understanding of the formative events is enhanced by recognition of both erosional and depositional features and their interrelationships within the landscape of the site.

\section{Conclusion}

In the fetch-restricted Mediterranean domain we have drawn attention to the occurrence of features attributed by Bryant \& Young (1996) to erosion by extreme waves. Some erosional signatures are clearly distinctive and, whilst other rock coast forms may sometimes be subtle and ambiguous, collectively they form patterns and associations that if replicated elsewhere may have the potential to attain characteristic assemblage status.

The distribution of erosional features provides evidence of the magnitude and intensity of flow of overwashing waves affected by bathymetry, topography and rock structure and lithology. It highlights the most exposed locations (erosional hotspots) and, in combination with depositional evidence, aids interpretation of the direction of wave attack and run-up flow. On the Maltese Islands where resort developments occupy many of the NE facing shorelines, headlands and low cliffs including their immediate hinterlands are identified as potentially hazardous locations, especially where deep water extends inshore.

Spillways or low cols existing on headland promontories are identified as critical locations in the study of the effects of extreme waves on rocky coastlines. The col presents a range of cliff and hillslope elevations that will be assailed by wave impacts and overwashing flow allowing zones of erosion, transition and deposition to be identified, and assisting identification of the maximum elevations of wave impact and run-up. 
We show that retrodictions of the assailing waves based on erosion features themselves are in some cases feasible, and may complement previous approaches relying solely on boulders. Unlike transported boulders, however, erosion features identify the exact point of wave impact and rock detachment and are resilient against subsequent episodes of transport or human interference. However, we caution that assumptions relating to the detachment process mean that such techniques should not be used as the sole means on which to base conclusions. Instead, it is recommended that depositional evidence, especially boulders and the sequencing of erosion and deposition features are also applied to compile a conceptual model of extreme wave impact and flow across the coastal landscape. By applying such a blend of quantitative and qualitative assessments it can be possible to differentiate between the effects of storm and tsunami waves in shaping the rock coast environment. Our contention in the case of the Maltese islands, which lie within an area of known historic tsunami activity, is that a moderate but significant proportion of the features in this study lie significantly beyond the formative capabilities of the known contemporary extreme storm wave climate.

In final conclusion, we suggest that Bryant and Young's (1996) entreaty to tsunamologists to seek these erosional forms in contrasting settings remains valid; we would reiterate it and commend others to seek further instances in the Mediterranean context and elsewhere, especially in landscapes developed on different lithologies. In this way a more comprehensive view of their distributions, associations and characteristics and a better understanding of their significance may be developed. As such this paper contributes to parts of the generic research agenda initiated by Courtney et al., (2012).

\section{Acknowledgements}

Field support: Alastair Pearson, Martin Schaefer, Linley Hastewell, Ritienne Gauci, Julian Evans, Fraser Houston; Geological advice: Graham Wilson, Martyn Pedley; Cartography: Bill Johnson, Paul Carter; Technical support: Paul Carter; Maltese advice: Darren Bianco, Robert Cachia, John Schembri, Frank Ventura, Charles Galdies, Joe Bianco, Antony Caruana; Financial support: Department of Geography, University of Portsmouth.

We are particularly indebted to two anonymous reviewers who, whilst generously offering supportive advice, asked critical and penetrating questions which have resulted in a much improved outcome. 
Address of authors: Department of Geography, University of Portsmouth, Buckingham Building, Lion Terrace, PORTSMOUTH, Hampshire, UK. PO1 3HE.

\section{$\underline{\text { References }}$}

Aalto KR, Aalto R, Garrison-Laney CE, Abramson HF. 1999. Tsunami(?) sculpturing of the Pebble Beach wave-cut platform, Crescent City area, California. The Journal of Geology 107.5: 607-622.

Barbano MS, Pirrotta C, Gerardi F. 2010. Large boulders along the south-eastern Ionian coast of Sicily: Storm or tsunami deposits? Marine Geology 275 (1-4): 140-154.

Benner R, Browne T, Brückner H, Kelletat D, Scheffers A. 2010. Boulder Transport by Waves: Progress in Physical Modelling. Zeitschrift für Geomorphologie Supplementary Issue 54.3:127-146.

Bourgeois J. 2009. Geological effects and records of tsunamis. In The Sea, Volume 15, Ch. 3 Tsunamis. Robinson AR, Bernard EN. (eds). Harvard University Press: Cambridge; 53-91.

Bourgeois J, Maclnnes B. 2010. Tsunami boulder transport and other dramatic effects of the 15 November 2006 central Kuril Islands tsunami on the island of Matua. Zeitschrift für Geomorphologie Supplementary Issue 54.3, 175-195.

Bryant E. 2001. Tsunami - the underrated hazard. 1E. Cambridge University Press: Cambridge.

Bryant E. 2014. Tsunami - the underrated hazard. 3E. Praxis Publishing: Chichester.

Bryant EA, Haslett S. 2007. Catastrophic Wave Erosion, Bristol Channel, United Kingdom: Impact of Tsunami? The Journal of Geology 115: 253-269. 
Bryant EA, Young RW. 1996. Bedrock-sculpturing by tsunami, South coast New South Wales, Australia. The Journal of Geology 104: 565-582.

Cassar J. 2010. The use of limestone in a historic context - the experience of Malta. Geological Society, London, Special Publication 331: 3-25. doi: 10.1144/SP331.2.

Cassar J, Marrocchi A, Santarelli ML, Muscat M. 2008. Controlling crystallization damage by the use of salt inhibitors on Malta's limestone. Materiales de Construcción 58: 281-293.

Cita MB, Camerlenghi A, Rimoldi B. 1996. Deep-sea tsunami deposits in the eastern Mediterranean: new evidence and depositional models. Sedimentary Geology 104: 155173.

Cita MB, Aloisi G. 2000. Deep-sea tsunami deposits triggered by the explosion of Santorini (3500 y BP), eastern Mediterranean. Sedimentary Geology, 13.5: 181-203.

Courtney C, Dominey-Howes D, Goff J, Chagué-Goff C, Switzer A, McFadgen B. 2012. A synthesis and review of the geological evidence for palaeotsunamis along the coast of southeast Australia: the evidence, issues and potential ways forward. Quaternary Science Reviews 54: 99-125.

Dawson AG. 2003. Tsunami - the underrated hazard (E Bryant). Journal of Quaternary Science 18.6: 582.

Drago A. 2008. Numerical modelling of coastal seiches in Malta. Physics and Chemistry of the Earth 33: 260-275.

Drago A. 2009. Sea level variability and the 'Milghuba' seiche oscillations in the northern coast of Malta, Central Mediterranean. Physics and Chemistry of the Earth 34: 948-970.

Drago A, Azzopardi J, Gauci A, Tarasova R, Bruschi A. 2013. Assessing the offshore wave energy potential for the Maltese Islands. Institute for Sustainable Energy, University of Malta, Annual Conference, 21st March 2013, Qawra, Malta. 
Dornbusch U, Robinson DA. 2011. Block removal and step backwearing as erosion processes on rock shore platforms: a preliminary case study of the chalk shore platforms of south-east England. Earth Surface Processes and Landforms 36: 661-671.

Emanuel KA. 2005. Genesis and maintenance of "Mediterranean hurricanes". Advances In Geoscience 2: 217-220.

Engel M, May SM. 2012. Bonaire's boulder fields revisited: evidence for Holocene tsunami impact on the Leeward Antilles. Quaternary Science Reviews 54:126-141. doi:10.1016/j.quascirev.2011.12.011.

Etienne S, Paris R. 2010. Boulder accumulations related to storms on the south coast of the Reykjanes Peninsula (Iceland). Geomorphology 114: 55-70.

Felton EA, Crook KAW. 2003. Evaluating the impacts of huge waves on rocky shorelines: an essay review of the book 'Tsunami - The Underrated Hazard'. Marine Geology 197: 112.

Fita L, Romero R, Luque A, Emanuel K, Ramis C. 2007. Analysis of the environments of seven Mediterranean tropical-like storms using an axisymmetric, nonhydrostatic, cloud resolving model. Natural Hazards Earth System Science 7, 41-56.

Goto K, Kawana T, Imamura F. 2010. Historical and geological evidence of boulders deposited by tsunamis, southern Ryukyu Islands, Japan. Earth Science Reviews 102: 7799.

Goto K, Miyagi K, Kawana T, Takahashi J, Imamura F. 2011. Emplacement and movement of boulders by known storm waves - Field evidence from the Okinawa Islands, Japan. Marine Geology 283: 66-78.

Hall AM, Hansom JD, Williams DM, Jarvis J. 2006. Distribution, geomorphology and lithofacies of cliff-top storm deposits: Examples from the high-energy coasts of Scotland and Ireland. Marine Geology 232:131-155. 
Hall AM, Hansom JD, Jarvis J. 2008. Patterns and rates of erosion produced by high energy wave processes on hard rock headlands: The Grind of the Navir, Shetland, Scotland. Marine Geology 248: 28-46.

Hansom JD, Barltrop NDP, Hall AM. 2008. Modelling the processes of cliff-top erosion and deposition under extreme storm waves. Marine Geology 253: 36-50.

Houston FK. 2014. High-energy boulder deposits on the Maltese Islands: Evaluation and inter-comparison of the nearshore and onshore. BSc dissertation: University of Portsmouth.

Kastens KA, Cita MB. 1981. Tsunami induced sediment transport in the abyssal Mediterranean Sea. Geological Society America Bulletin 89: 591-604.

Knight J, Burningham H, Barrett-Mold C. 2009. The geomorphology and controls on development of a boulder-strewn rock platform, NW Ireland. Journal of Coastal Research, Special Issue 56: 1646-1650. ISSN 0749-0258.

Knight, J., Burningham, H. (2011). Boulder dynamics on an Atlantic-facing rock coastline, northwest Ireland. Marine Geology 283: 56-65.

Lionello P, Bhend J, Buzzi A, Della-Marta PM, Krichak S, Jansa A, Maheras P, Sanna A, Trigo IF, Trigo R. 2006. Cyclones in the Mediterranean region: climatology and effects on the environment. In Lionello P, Malanotte-Rizzoli P, Boscolo R. (eds) Mediterranean Climate Variability. Amsterdam: Elsevier (Netherlands); 324-372.

Maouche S, Morhange C, Meghraoui M. 2009. Large boulder accumulation on the Algerian coast evidence tsunami events in the western Mediterranean. Marine Geology 262: 96-104.

Maramai A, Brizuela B, Graziani L. 2014. The Euro-Mediterranean tsunami catalogue. Annals of Geophysics 57.4, S0435. doi:10.4401/ag-6437.

Mastronuzzi G, Sansó P. 2004. Large boulder accumulations by extreme waves along the Adriatic coast of southern Apulia (Italy). Quaternary International 120:173-184. 
Mastronuzzi G, Pignatelli C, Sansò P. 2006. Boulder fields: A valuable morphological indicator of palaeotsunami in the Mediterranean Sea. Zeitschrift für Geomorphologie Supplementary Issue 146:173-194.

Mastronuzzi G, Pignatelli C, Sansò P, Selleri, G. 2007. Boulder accumulations produced by the 20th of February, 1743 tsunami along the coast of southeastern Salento (Apulia region, Italy). Marine Geology 242, 1-3: 191-205.

Mottershead D, Bray M, Soar P, Farres PJ. 2014. Extreme wave events in the central Mediterranean: Geomorphic evidence of tsunami on the Maltese islands. Zeitschrift für Geomorphologie: 58.3, 385-411.

Mottershead DN, Bray MB, Causon Deguara J. (Under review). Tsunamigenic landscapes in the Maltese Islands: The Comino Channel coasts. In Gauci R, Schembri JA (eds). Landscapes and Landforms of the Maltese Islands. Springer Press.

Moscatello A, Miglietta MM, Rotunno R. 2008. Observational analysis of a Mediterranean 'hurricane' over south-eastern Italy. Weather 63.10: 306-311.

Nandasena NAK, Paris R, Tanaka N. 2011. Reassessment of hydrodynamic equations: Minimum flow velocity to initiate boulder transport by high energy events (storms, tsunamis). Marine Geology 281: 70-84.

Naylor LA, Stephenson WJ. 2010. On the role of discontinuities in mediating shore platform erosion. Geomorphology 114: 89-100.

Noormets R, Crook KAW, Felton EA. 2004. Sedimentology of rocky shorelines: 3. Hydrodynamics of megaclast emplacement and transport on a shore platform, Oahu, Hawaii. Sedimentary Geology 172: 41-65.

Nott J. 1997. Extremely high-energy wave deposits inside the Great Barrier Reef, Australia: determining the cause - tsunami or tropical cyclone. Marine Geology 141: 193-207.

Nott J. 2003. Waves, coastal boulder deposits and the importance of the pre-transport setting. Earth \& Planetary Science Letters 210: 269-276. 
Nott J, Bryant E. 2003. Extreme marine inundations (Tsunamis?) of Western Australia. The Journal of Geology 111.6: 691-706.

Oliviera MA, Andrade C, Freitas MC, Costa P, Taborda R, Janardo C, Neves R. 2011. Transport of large boulders quarried from shore platforms of the Portuguese west coast. Journal of Coastal Research Special Issue 64: 1871-1875. ISSN 0749-0208 Poland.

Paris R, Naylor LA, Stephenson WJ. 2011. Boulders as a signature of storms on rock coasts. Marine Geology 283: 1-11.

Pedley HM. 1978. A new lithostratigraphical and palaeoenvironmental interpretation for the coralline limestone formations (Miocene) of the Maltese Islands. Overseas Geology and Mineral Resources 54. Institute of Geological Sciences, HMSO: London.

Pedley HM, House MR, Waugh B. 1976a. The Geology of Malta and Gozo. Proceedings, Geological Association 87.3: 325-341.

Pedley HM, Waugh B. 1976b. Easter Field Meeting to the Maltese Islands, 7-14 April 1974. Proceedings, Geological Association 87.3: 343-385.

Pedley M, Clarke MH, Galea P. 2002. Limestone Islands in a Crystal Sea. Publishers Enterprise Group: Malta.

Pignatelli C, Sansò P, Mastronuzzi G. 2009. Evaluation of tsunami flooding using geomorphologic evidence. Marine Geology 260: 6-18.

Pignatelli C, Scheffers A, Scheffers S, Mastronuzzi, G. 2010. Assessment of extreme wave flooding from geomorphologic evidence in Bonaire (Netherlands Antilles). Zeitschrift für Geomorphologie Supplementary Issue 54.3: 219-245.

Polonia A, Bonatti E, Camerlenghi A, Lucchi RG, Panieri G, Gasperini L. (2013): Mediterranean megaturbidite triggered by the AD 365 Cretan earthquake and tsunami. - Science Report 3. doi:10.1038/srep01285.

Scheffers A, Kelletat D. 2003. Sedimentologic and geomorphologic tsunami imprints worldwide: a review. Earth Science Reviews 63: 83-92.

Scicchitano G, Monaco C, Tortorici L. 2007. Large boulder deposits by tsunami waves along the lonian coast of south-eastern Sicily (Italy). Marine Geology 238: 75-91. 
Shah-Hosseini M, Morhange C, De Marco A, Wante J, Anthony EJ, Sabatier F, Mastronuzzi G, Pignatelli C, Piscitelli A. 2013. Coastal boulders in Martigues, French Mediterranean: evidence for extreme storm waves during the Little Ice Age. Zeitschrift für Geomorphologie Supplementary Issue 57.4: 181-199. DOI: 10.1127/03728854/2013/00132.

Shaw B, Ambraseys NN, England PC, Floyd MA, Gorman GJ, Higham TFG, Jackson JA, Nocquet J-M, Pain CC, Piggott MD. 2008. Eastern Mediterranean tectonics and tsunami hazard inferred from the AD 365 earthquake. Nature Geoscience 1 (April): 268-276. doi:10.1038/ngeo151.

Stephenson WJ, Naylor LA. 2011. Geological controls on boulder production in a rock coast setting: Insights from South Wales, UK. Marine Geology 283: 12-24.

Synolakis CE. 1987. Runup of solitary waves. Journal of Fluid Mechanics 185: 523-545.

Synolakis CE.1991. Tsunami runup on steep slopes: How good linear theory really is. Natural Hazards 4: 221-234.

UK Hydrographic Office (2008) Chart 211. Plans in the Maltese Islands. U.K. Hydrographic Office, Taunton.

Umitsu M, Tanavud C, Patanakanog B. 2007. Effects of landforms on tsunami flow in the plains of Banda Aceh, Indonesia, and Nam Khem, Thailand. Marine Geology 242: 141153.

Address of authors: Department of Geography, University of Portsmouth, Buckingham Building, Lion Terrace, PORTSMOUTH, Hampshire, UK. PO1 3HE.

Corresponding author: Dr. M. Bray, malcolm.bray@port.ac.uk, tel. 442392842481 , fax. 222392842512. 
Tables

Table 1: Fetches available for generation of storm waves arriving on Maltese shorelines. p.3

\begin{tabular}{|l|c|c|}
\hline \multicolumn{1}{|c|}{ Coast } & Aspect & Fetch (km) \\
\hline Sicily & $\mathrm{N}$ & 90 \\
\hline Hellenic & $\mathrm{NE}$ & 600 \\
\hline Lebanon/ Israel & $\mathrm{E}$ & 1900 \\
\hline Libya & $\mathrm{SE}$ & 720 \\
\hline Libya & $\mathrm{S}$ & 340 \\
\hline Tunisia & $\mathrm{SW}$ & 450 \\
\hline Tunisia & $\mathrm{W}$ & 300 \\
\hline Balearic & $\mathrm{NW}$ & 1200 \\
\hline
\end{tabular}

Table 2: The geological succession of the Maltese Islands. p.4

\begin{tabular}{|c|c|c|c|}
\hline Epoch & Formation & Composition & Physical character \\
\hline Miocene & $\begin{array}{l}\text { Upper } \\
\text { Coralline } \\
\text { Limestone }\end{array}$ & $\begin{array}{l}\text { Peloidal and molluscan } \\
\text { carbonate mudstones containing } \\
\text { reefs. }\end{array}$ & $\begin{array}{l}\text { Variable composition, high biotic } \\
\text { content, sometimes incoherent. } \\
\text { Strongly bedded, } 0.25-1.5 \mathrm{~m} \\
\text { depth, densely jointed. }\end{array}$ \\
\hline Miocene & Blue Clay & Blue clay. & $\begin{array}{l}\text { Coastal mass movement forms, } \\
\text { not conducive to retention of } \\
\text { extreme wave signatures. }\end{array}$ \\
\hline Miocene & $\begin{array}{l}\text { Globigerina } \\
\text { Limestone }\end{array}$ & $\begin{array}{l}\text { Soft buff limestone, containing } \\
\text { phosphorite conglomerate beds } \\
\text { (PCB) and hard basal limestone. }\end{array}$ & $\begin{array}{l}\text { Massive coherent rock, bedding } \\
\text { planes } 1-1.5 \mathrm{~m} \text { spacing; } \\
\text { PCB } \sim 0.5 \mathrm{~m} \text { thick. }\end{array}$ \\
\hline Oligocene & $\begin{array}{l}\text { Lower } \\
\text { Coralline } \\
\text { Limestone }\end{array}$ & Grey/ brown limestones. & $\begin{array}{l}\text { Compact rocks, bedding plane } \\
\text { joints } 1-2 \text { m spacing. }\end{array}$ \\
\hline
\end{tabular}

Table 3: Mechanical properties of rock types in this study (after Cassar 2010). p.4 


\begin{tabular}{|l|c|c|}
\hline \multicolumn{1}{|c|}{ Formation } & Specific Gravity & $\begin{array}{c}\text { Dry Uniaxial Compressive } \\
\text { Strength (MPa) }\end{array}$ \\
\hline Upper Coralline Limestone & $2.05-2.52$ & $8.8-67.2$ \\
\hline Lower Coralline Limestone & $2.43-2.65$ & $6.8-105$ \\
\hline Globigerina Limestone & $2.35-2.61$ & $15.0-32.9$ \\
\hline
\end{tabular}

Table 4: Topographic characteristics of principal study sites. p.4

\begin{tabular}{|c|c|c|c|c|}
\hline Site & Planform & Profile & Relief & Lithology \\
\hline Aћrax & Peninsula & Cliffed ridge with col & Up to $>20 \mathrm{~m}$ & U. Coralline \\
\hline Ghemieri & Peninsula & Cliffed ridge with col & Up to $>20 \mathrm{~m}$ & U. Coralline \\
\hline Qorrot & Linear & Ramp over sea cliff & Up to $>12 \mathrm{~m}$ & Globigerina \\
\hline Quarry & Linear & Ramp over sea cliff & Up to $>15 m$ & L. Coralline \\
\hline San Niklau & Linear & Ramp & Up to $12 \mathrm{~m}$ & U. Coralline \\
\hline South Comino & Linear & Ramp & Up to $12 \mathrm{~m}$ & U. Coralline \\
\hline Water Park & $\begin{array}{l}\text { Promontor } \\
\text { y }\end{array}$ & Platform & $<1 \mathrm{~m}$ & L. Coralline \\
\hline White Tower & $\begin{array}{l}\text { Promontor } \\
\mathrm{y}\end{array}$ & Slope over platform & Up to $14 \mathrm{~m}$ & U. Coralline \\
\hline Xghajra & Linear & Platforms over sea cliff & Up to $>8 \mathrm{~m}$ & L. Coralline \\
\hline Żonqor & Linear & Serial rock platforms & Up to $18 \mathrm{~m}$ & Globigerina \\
\hline
\end{tabular}

Table 5: Classification of Erosional Forms. p.5, 15

\begin{tabular}{|l|l|l|}
\hline \multicolumn{1}{|c|}{ Primary Force } & \multicolumn{1}{c|}{ Process } & \multicolumn{1}{c|}{ Feature } \\
\hline Lift & Block removal & $\begin{array}{l}\text { Sockets, } \\
\text { Megasockets }\end{array}$ \\
\hline Lift + shear & Block removal & $\begin{array}{l}\text { Clifftop detachment } \\
\text { scars }\end{array}$ \\
\hline
\end{tabular}




\begin{tabular}{|l|l|l|}
\hline \multirow{2}{*}{ Shear } & $\begin{array}{l}\text { Block removal/ } \\
\text { Abrasion }\end{array}$ & $\begin{array}{l}\text { Eroded scarps } \\
\text { Megasockets }\end{array}$ \\
\cline { 2 - 3 } & Abrasion & Scoured terrain \\
\cline { 2 - 3 } & Abrasion & Swept terrain \\
\hline
\end{tabular}

Table 6: Distribution of Erosion Features by Study Site. p.5

\begin{tabular}{|c|c|c|c|c|c|c|}
\hline \multirow[t]{2}{*}{ SITE } & \multirow{2}{*}{$\begin{array}{c}\text { LIFT } \\
\text { Sockets }\end{array}$} & \multicolumn{2}{|c|}{ SHEAR + LIFT } & \multicolumn{3}{|c|}{ SHEAR } \\
\hline & & $\begin{array}{l}\text { Clifftop } \\
\text { scar }\end{array}$ & $\begin{array}{l}\text { Eroded } \\
\text { scarp }\end{array}$ & $\begin{array}{c}\text { Scoured } \\
\text { terrain }\end{array}$ & \begin{tabular}{|l} 
Spillway \\
\end{tabular} & $\begin{array}{c}\text { Swept } \\
\text { platform }\end{array}$ \\
\hline $\begin{array}{l}\text { Aћrax } \\
\text { Head }\end{array}$ & $T$ & & $T$ & 1 & & \\
\hline $\begin{array}{l}\text { Aћrax } \\
\text { ridge }\end{array}$ & T & T & & 1 & I & \\
\hline Gћemieri & 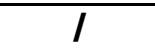 & & $T$ & $T$ & $T$ & $T$ \\
\hline Qorrot & & & $T$ & & & $T$ \\
\hline Quarry & & & $T$ & & & 1 \\
\hline S Comino & 1 & & & & & 1 \\
\hline San Niklau & & & & 1 & & \\
\hline Water Park & I & & & & & \\
\hline $\begin{array}{l}\text { White } \\
\text { Tower }\end{array}$ & $T$ & & $T$ & & & \\
\hline Xghajra & & & 1 & & & 1 \\
\hline Żonqor & & & $T$ & & & $T$ \\
\hline Total & 6 & $\overline{1}$ & 7 & 3 & 2 & 6 \\
\hline
\end{tabular}

Table 7: Socket field characteristics p.5

\begin{tabular}{|c|c|c|c|c|c|c|}
\hline Site & Bedrock & Location & $\begin{array}{l}\text { Length } \\
(\mathrm{m})\end{array}$ & $\begin{array}{l}\text { Width } \\
(\mathrm{m})\end{array}$ & $\begin{array}{l}\text { Altitude } \\
\text { (m asl) }\end{array}$ & $\begin{array}{l}\text { Distance } \\
\text { to sea }(m)\end{array}$ \\
\hline Aћrax Head & $\overline{\mathrm{UCL}}$ & At promontory & 60 & 55 & $\begin{array}{l}7.5- \\
13.5\end{array}$ & $20-85$ \\
\hline $\begin{array}{l}\text { Aћrax sea } \\
\text { side }\end{array}$ & $\overline{U C L}$ & $\begin{array}{l}\text { Seaward slope of Aћrax } \\
\text { ridge }\end{array}$ & 320 & 35 & $0-19$ & $0-50$ \\
\hline $\begin{array}{l}\text { Aћrax lee } \\
\text { side }\end{array}$ & UCL & $\begin{array}{l}\text { Leeward slope of Aћrax } \\
\text { ridge }\end{array}$ & 50 & 8 & 7 & 115 \\
\hline
\end{tabular}




\begin{tabular}{|c|c|c|c|c|c|c|}
\hline Aћrax valley & $\mathrm{UCL}$ & Axis of Aћrax valley & 15 & 4 & 5.5 & $110 / 140$ \\
\hline Water Park & LCL & Along NW margin of spit & 90 & 10 & $<1$ & $2-20$ \\
\hline White Tower & UCL & Head of coastal ramp & 80 & 30 & $3-5$ & $9-170$ \\
\hline
\end{tabular}

Table 8: Socket Parameters: White Tower and Aћrax sites. p.6

\begin{tabular}{|l|c|c|c|c|}
\hline Variable & Mean & Max & Min & $\begin{array}{c}\text { Interquartile } \\
\text { range }\end{array}$ \\
\hline $\begin{array}{l}\text { White Tower } \\
(\mathrm{n}=43)\end{array}$ & & & & \\
\hline a (m) & 1.64 & 3.10 & 0.90 & 0.70 \\
\hline b (m) & 1.16 & 2.00 & 0.60 & 0.40 \\
\hline c (m) & 0.60 & 0.90 & 0.30 & 0.20 \\
\hline a/c & 1.48 & 1.00 & 5.00 & 1.41 \\
\hline Box volume $\left(\mathrm{m}^{3}\right)$ & 1.12 & 4.14 & 0.32 & 1.00 \\
\hline Mass (t) & 2.46 & 9.11 & 0.71 & 2.22 \\
\hline $\begin{array}{l}\text { Ahrax } \\
(n=11)\end{array}$ & & & & \\
\hline a (m) & 2.92 & 6.30 & 1.60 & 2.00 \\
\hline b (m) & 2.23 & 3.60 & 1.40 & 1.00 \\
\hline c (m) & 0.97 & $1.45 / 1.30$ & 0.50 & 0.95 \\
\hline a/c & 3.24 & 6.20 & 1.17 & 2.25 \\
\hline Box volume $\left(\mathrm{m}^{3}\right)$ & 7.08 & 18.84 & 1.57 & 10.25 \\
\hline Mass (t) & 15.58 & 41.44 & 3.45 & 22.53 \\
\hline
\end{tabular}

Table 9: Location and depth characteristics of sockets at Aћrax, Water Park and White Tower sites. Maximum storm and tsunami wave heights retrodicted from maximum socket depth values. p.15

\begin{tabular}{|l|c|c|c|c|c|c|}
\hline \multicolumn{1}{|c|}{ Site } & $\mathbf{n}$ & $\begin{array}{c}\text { Altitude } \\
(\mathbf{m} \text { asl) }\end{array}$ & $\begin{array}{c}\text { Distance } \\
\text { to sea }(\mathbf{m})\end{array}$ & $\begin{array}{c}\text { Depth } \\
(\mathbf{m})\end{array}$ & $\begin{array}{c}\text { Max } \mathbf{H}_{\mathbf{s}} \\
(\mathbf{m})\end{array}$ & $\begin{array}{c}\mathbf{M a x}_{\mathbf{t}} \\
(\mathbf{m})\end{array}$ \\
\hline Ahrax Head & 10 & $8-13.5$ & $20-85$ & $0.5-1.3$ & 8.94 & 2.23 \\
\hline Ahrax cliff & 4 & $2-8.5$ & $0-50$ & $0.3-1.2$ & 8.26 & 2.06 \\
\hline Ahrax & 2 & 5.5 & $110 / 140$ & $0.3-0.7$ & 4.81 & 1.20 \\
\hline
\end{tabular}




\begin{tabular}{|l|c|c|c|c|c|c|}
\hline valley & & & & & & \\
\hline Water Park & 8 & 0.5 & $2-20$ & $0.4-0.7$ & 5.81 & 1.45 \\
\hline $\begin{array}{l}\text { White } \\
\text { Tower }\end{array}$ & 43 & 5.0 & $9-45$ & $0.3-0.9$ & 6.19 & 1.55 \\
\hline
\end{tabular}

Figure 1. Location map showing the Maltese Islands and the principal study sites (note that the Comino Col label embraces both the Ghemieri site (the promontory forming the NE point of Comino) and the San Niklau site, some 4-600 m to the west beyond Santa Marija Bay.

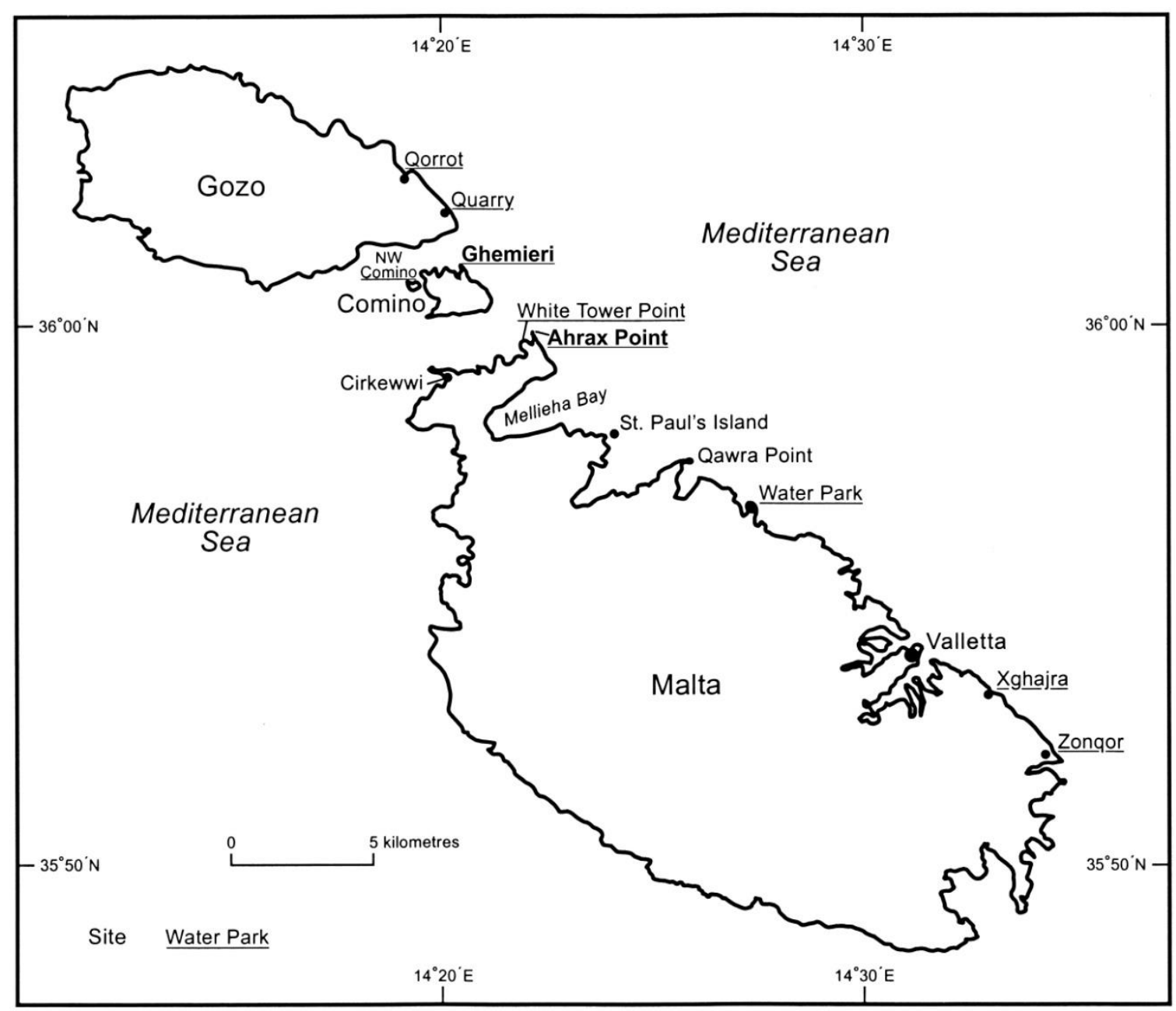


Figure 2. The distribution of erosional signatures at Aћrax study site. The major depositional signatures and inferred extreme wave flows are also shown to illustrate the local tsunamigenic context.

There is a predominance of erosional signatures on the slopes most exposed to the NE. Boulder deposition indicates decelerating flow and their alignments reveal the directions of that flow across and around the peninsula. Sand berms indicate deposition in calmer waters towards the limit of run up in the valley to the lee of the peninsula.

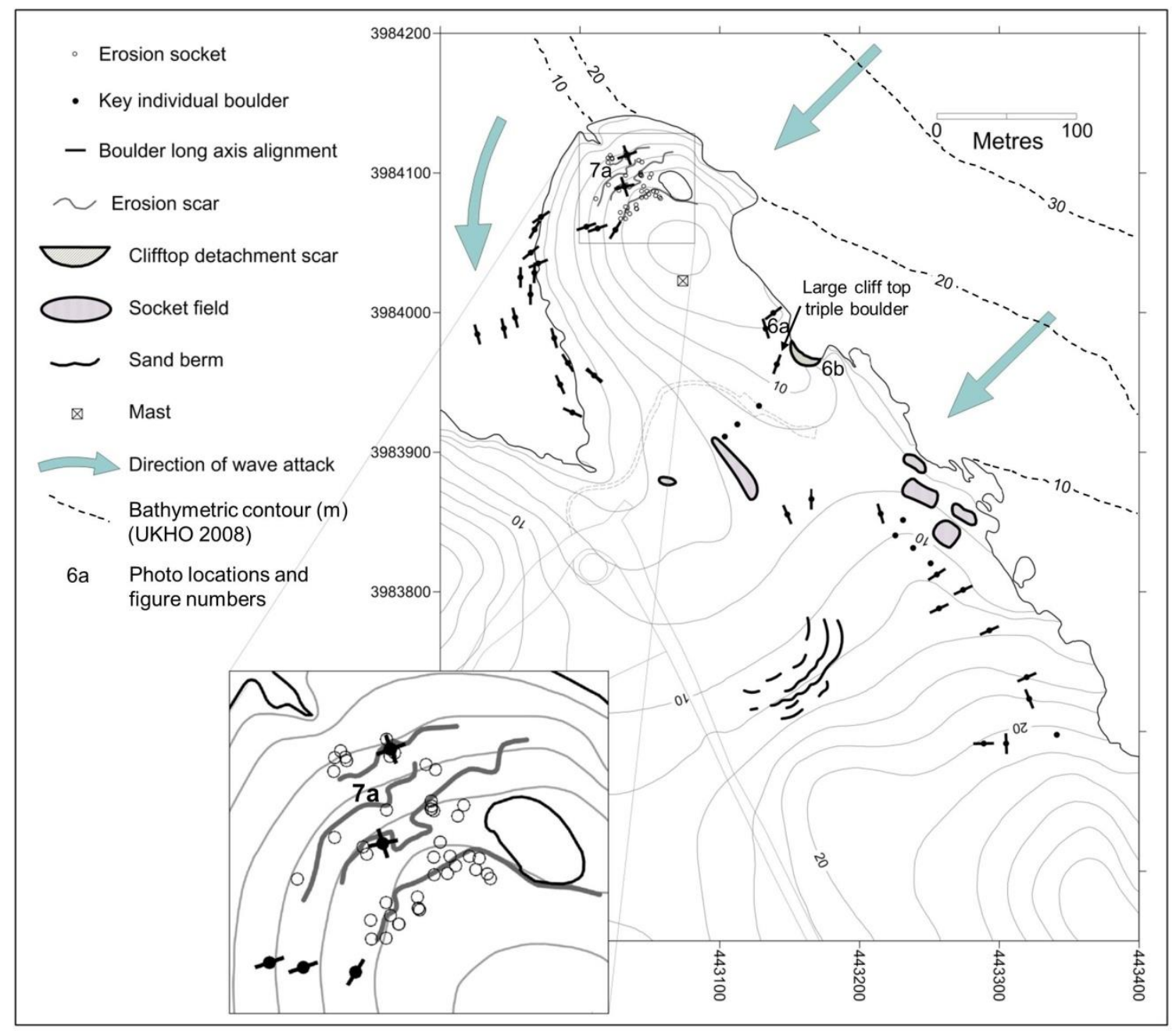


Figure 3. A line of contiguous sockets extending back from the foreground. The closest one holds a pool of water, whilst those in the background are occupied by boulders which they have trapped. White Tower site. The foreground socket wall is $\sim 0.6 \mathrm{~m}$ high.

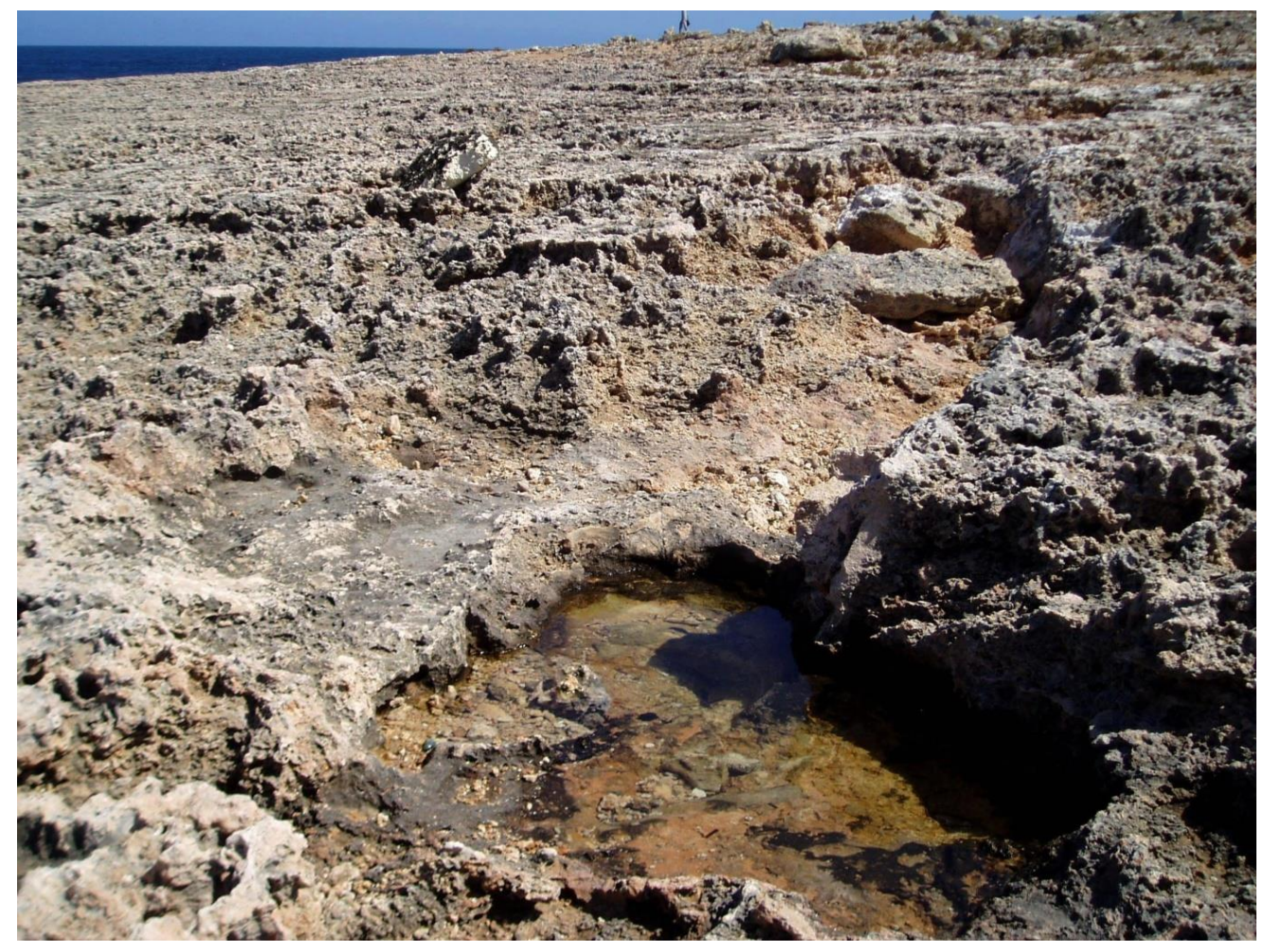


Figure 4. Boxplots of socket length and depth, White Tower site $(n=43)$, showing median, quartile and interquartile range values. The magnitude and variation of the length values are in strong contrast to those of depth, which is strongly constrained by bedding plane joint spacing (= lithological unit thickness).

White Tower

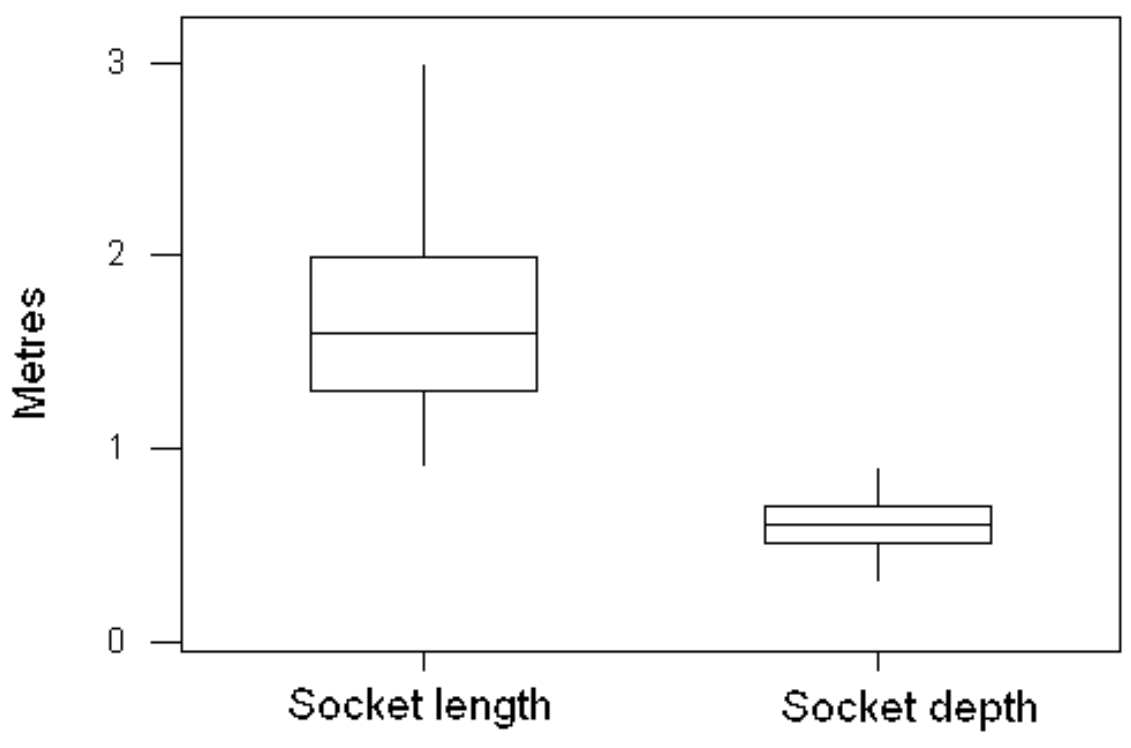


Figure 5. A megasocket some $2 \mathrm{~m}$ deep and $4 \mathrm{~m}$ in maximum diameter. Note the roughhewn and joint bounded socket walls; the floor contains cobbly/boulder sediment. Clearly a significant amount of rocky material has been excavated from this cavity. The scale of the feature and its nature is suggestive of high energy mechanical erosion processes; the basal debris, however, is not significantly rounded by abrasion. South Comino coast.

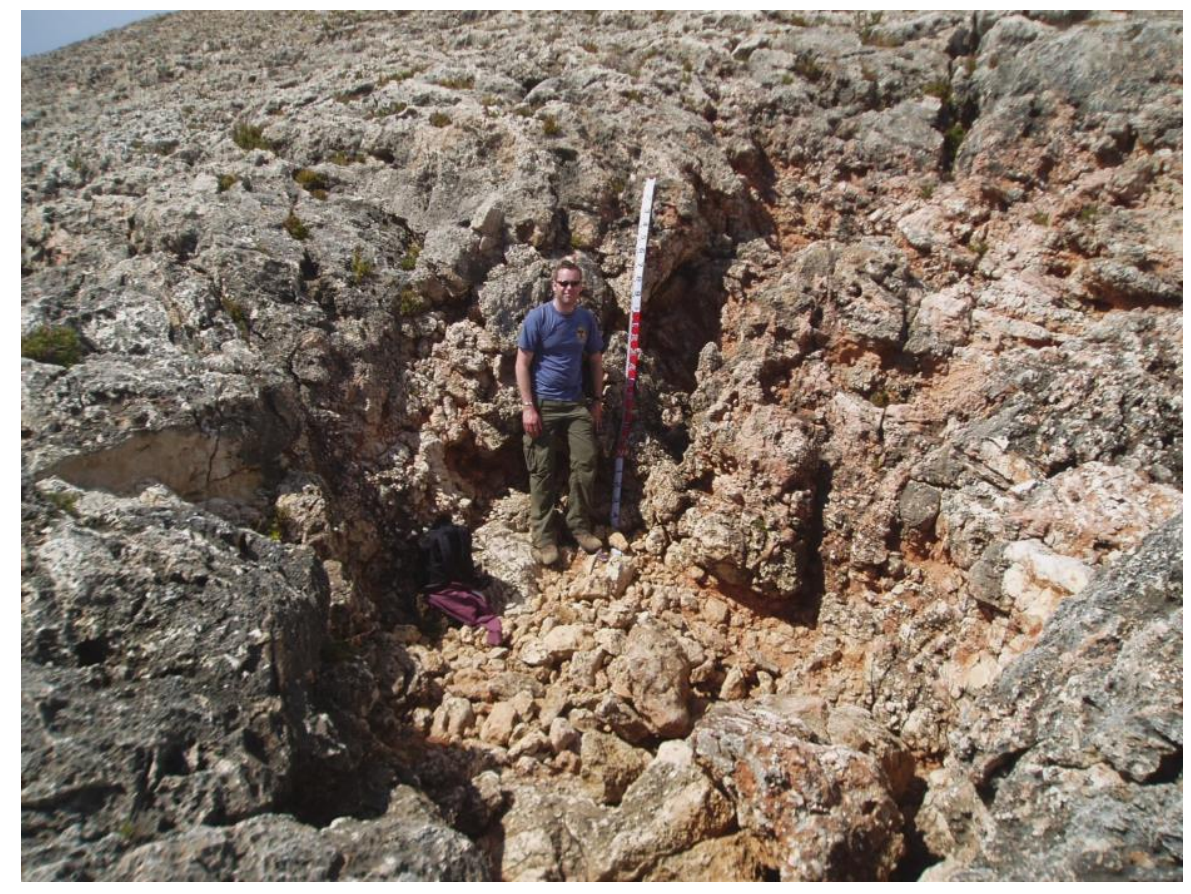


Figure 6a. Clifftop detachment scar at $10 \mathrm{~m}$ asl. A $7 \mathrm{~m}$ long triple fractured boulder is situated at R. Its source is most likely to have been the clifftop at the lower edge of the detachment scar over which an extreme wave flowed, shearing off a single joint bounded boulder and transporting it onshore and so forcibly depositing it that it fractured into three contiguous fragments. The model of Hansom et al (2008) suggests that a storm wave up to $17.3 \mathrm{~m}$ high or a tsunami wave $4.3 \mathrm{~m}$ high at this point would have been capable of doing that. The latter would have been the more likely in this Mediterranean moderate storm wave environment.

In the far distance a line of deposited boulders runs up to $>20 \mathrm{~m}$ asl, whilst the large foreground boulder forms part of a second boulder line, both shown by dotted lines. These two lines form a funnel leading toward a col at $7.3 \mathrm{~m}$ asl (out of shot), which acted as a spillway for a large flow overwashing the peninsula at this point. Such a flow is characteristic of tsunami.

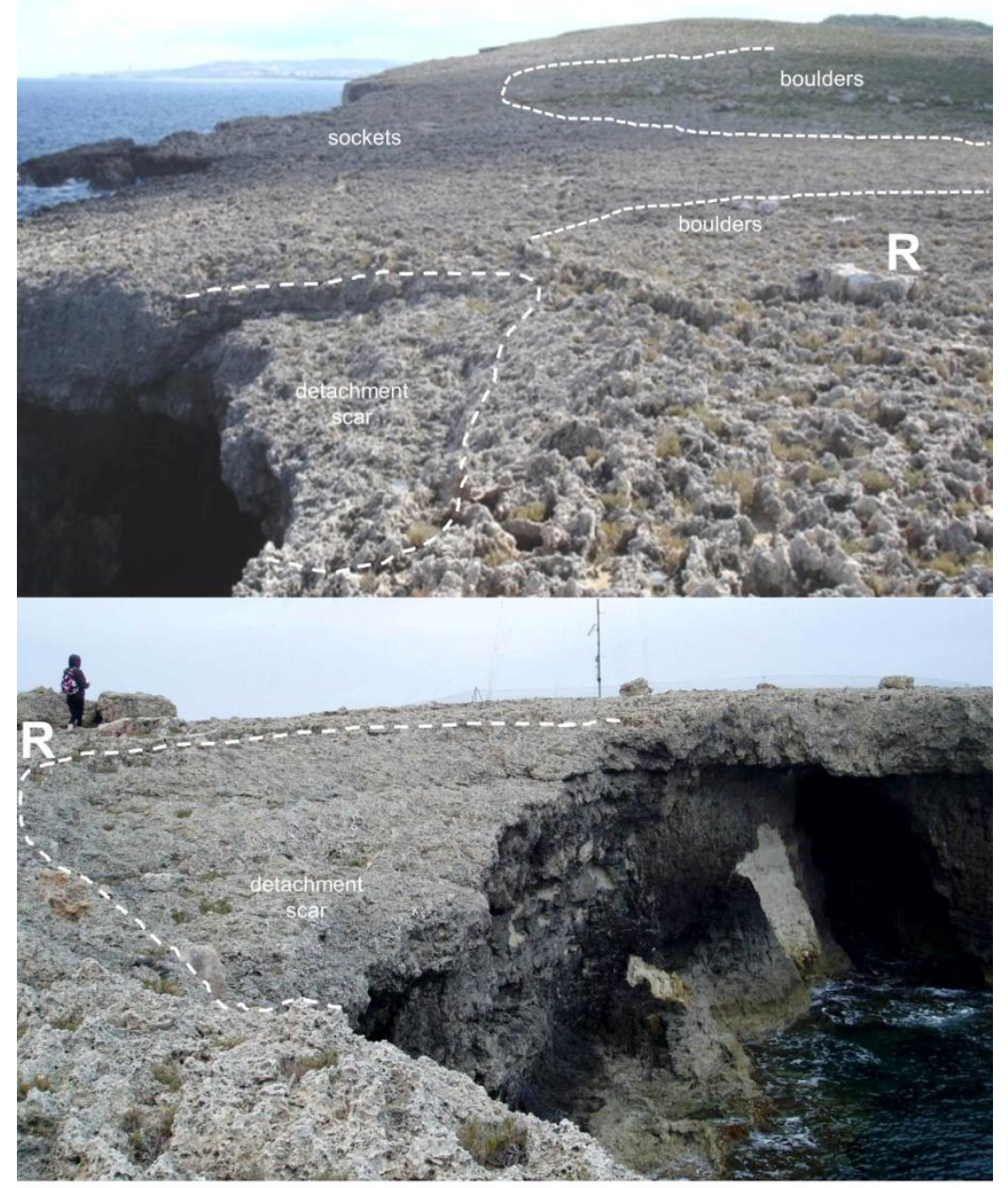

6b Alternative view of the same detachment scar and boulder looking NE. The cliff is near vertical and extends into deep water. This detachment scenario is modelled later in the present paper using a technique by Hansom et al (2008) to retrodict the wave that may have been responsible. 
Annotations better in black??? 
Figure 7a. Eroded scarp, three metres high, of linear planform formed by a rhodolithic limestone of Upper Coralline age at $11 \mathrm{~m}$ asl at Aћrax Head. The rock is not geometrically jointed, with the roughly hewn form reflecting variations in the internal structure of the rock. At the base of the scarp is an emergent bedding plane platform bearing the only clastic material present, a thin scatter of marine sand and occasional pebbles. At lower $\mathrm{R}$ are isolated pinnacles of bedrock of more rounded form, suggesting abrasion by the scouring effect of a sediment-laden flow.

This is interpreted as having been formed initially by boulder detachment, with subsequent abrasion of the pinnacles, by the overwashing flow of an extreme wave.

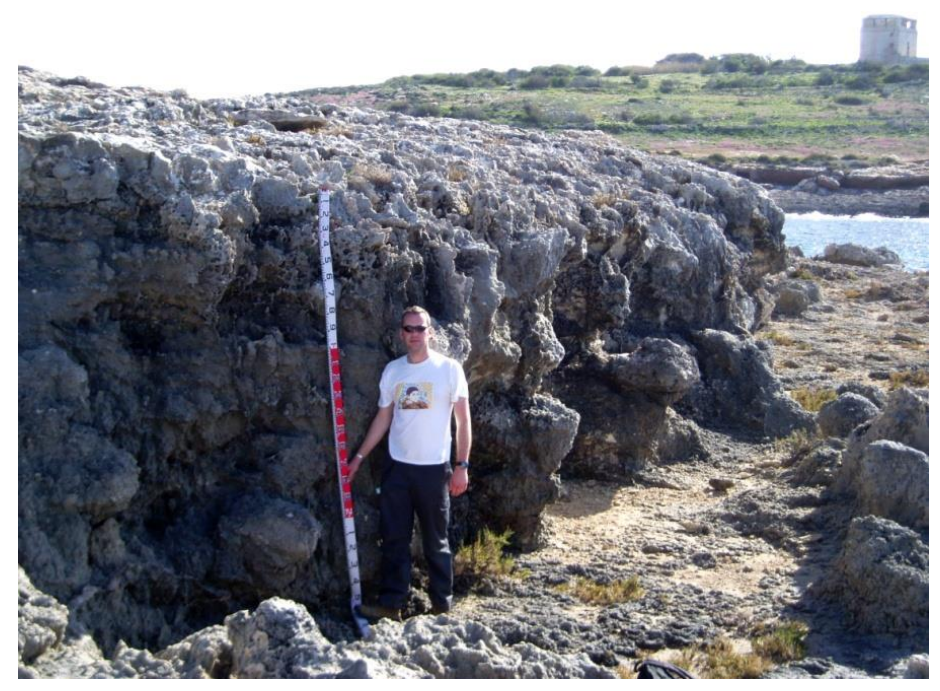

Figure 7b. An eroded scarp in a coherent Upper Coralline limestone bed, NW Comino. The scarp has been cleanly eroded back by boulder detachment to reveal stripped terrain in the foreground, formed by the underlying bedding plane. The stripped zone is some $15 \mathrm{~m}$ wide down to the water's edge at elevation $2.5 \mathrm{~m}$ asl. 


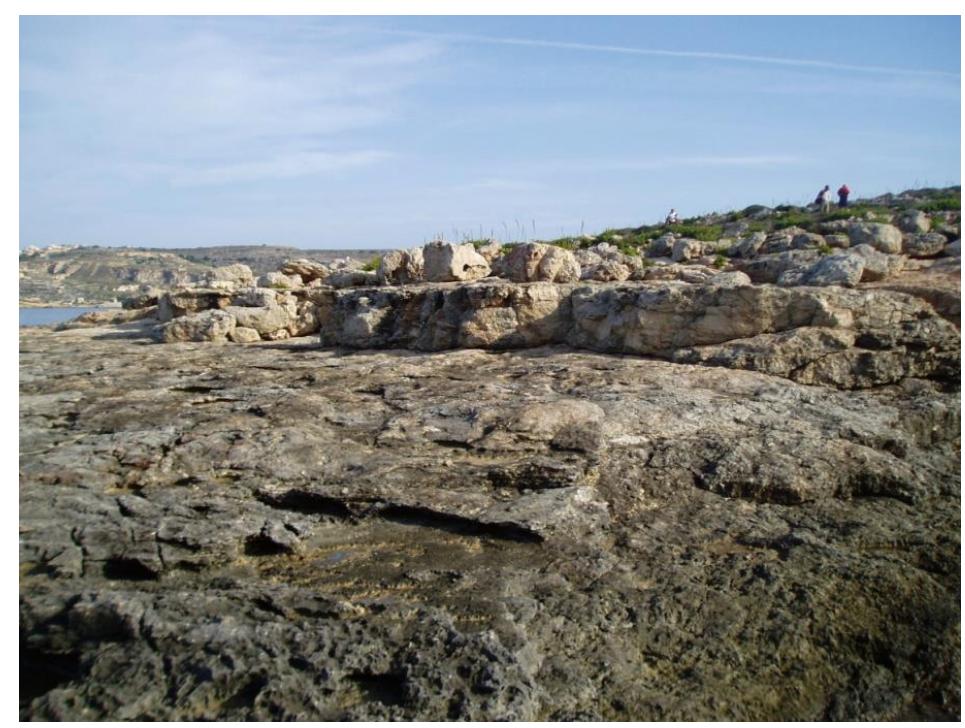

Figure 8. Scoured terrain, Ghemieri. A gully has been eroded out along a joint at $\sim 10$ asl running across a slope, and is partially backfilled by coarse sediment (large cobbles and small boulders). It has no topographically recognisable catchment area as a potential source of a vigorous flow of water. It is inferred that the flow was provided by an extreme wave washing over this headland, and any associated backwash. Such a flow would have been sufficiently energetic to erode the gully and also transport the large clasts now resting within it. 


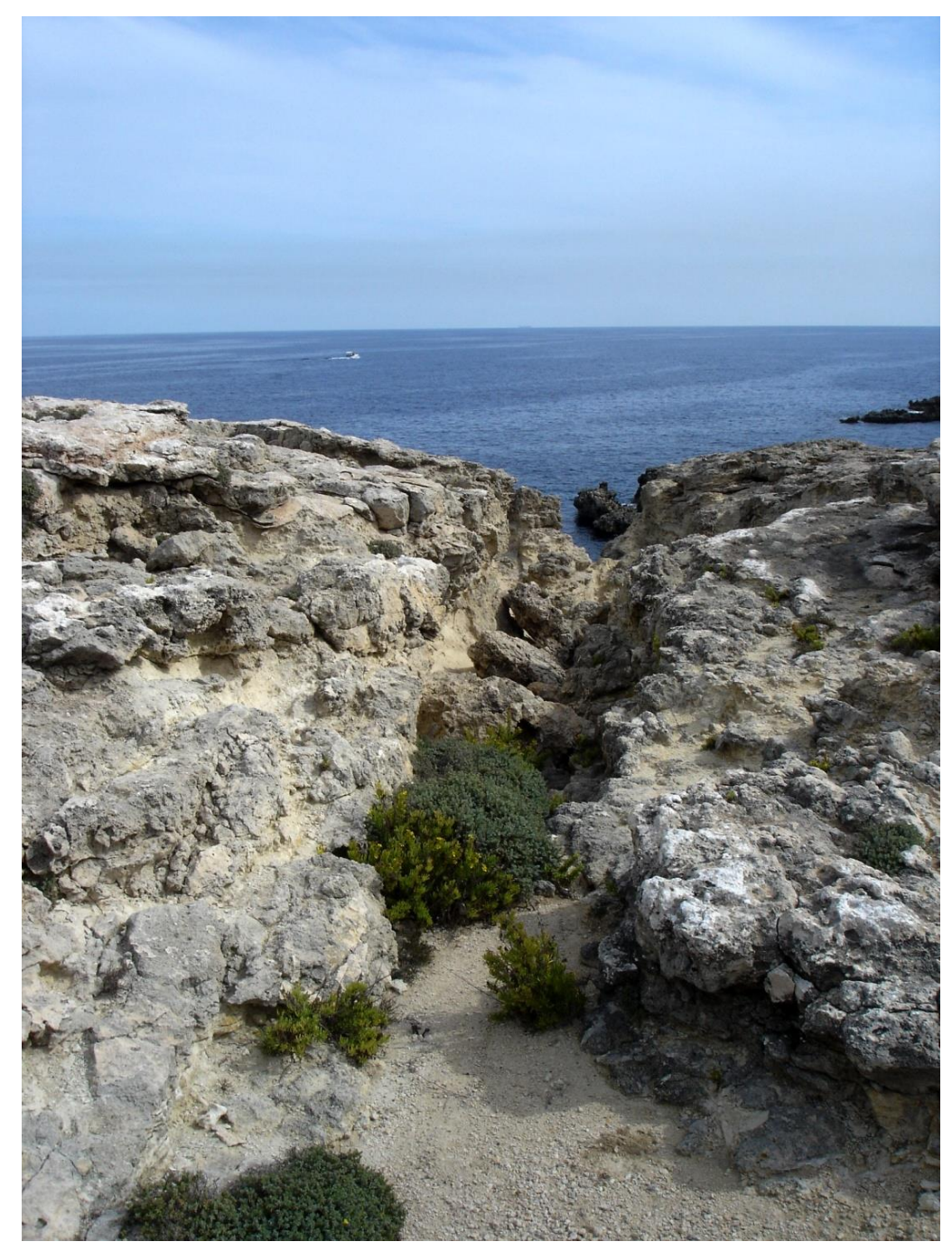


Figure 9. Ghemieri (Comino, showing the location of the aligned canyon (key item 4), boulder ramp and plunge pool, evidence of a constrained flow of high velocity. These forms are located within a complex distribution of erosion and deposition features. Field evidence indicates that the entire peninsula was overwashed to an elevation of at least $16 \mathrm{~m}$ asl. High energy erosion features occur along the exposed NE facing seaward margin with boulder and cobble deposits to the south west. (Base image Google Earth 15.06.2013). Note that Figure numbers are annotated onto this image to show locations of the relevant photos.

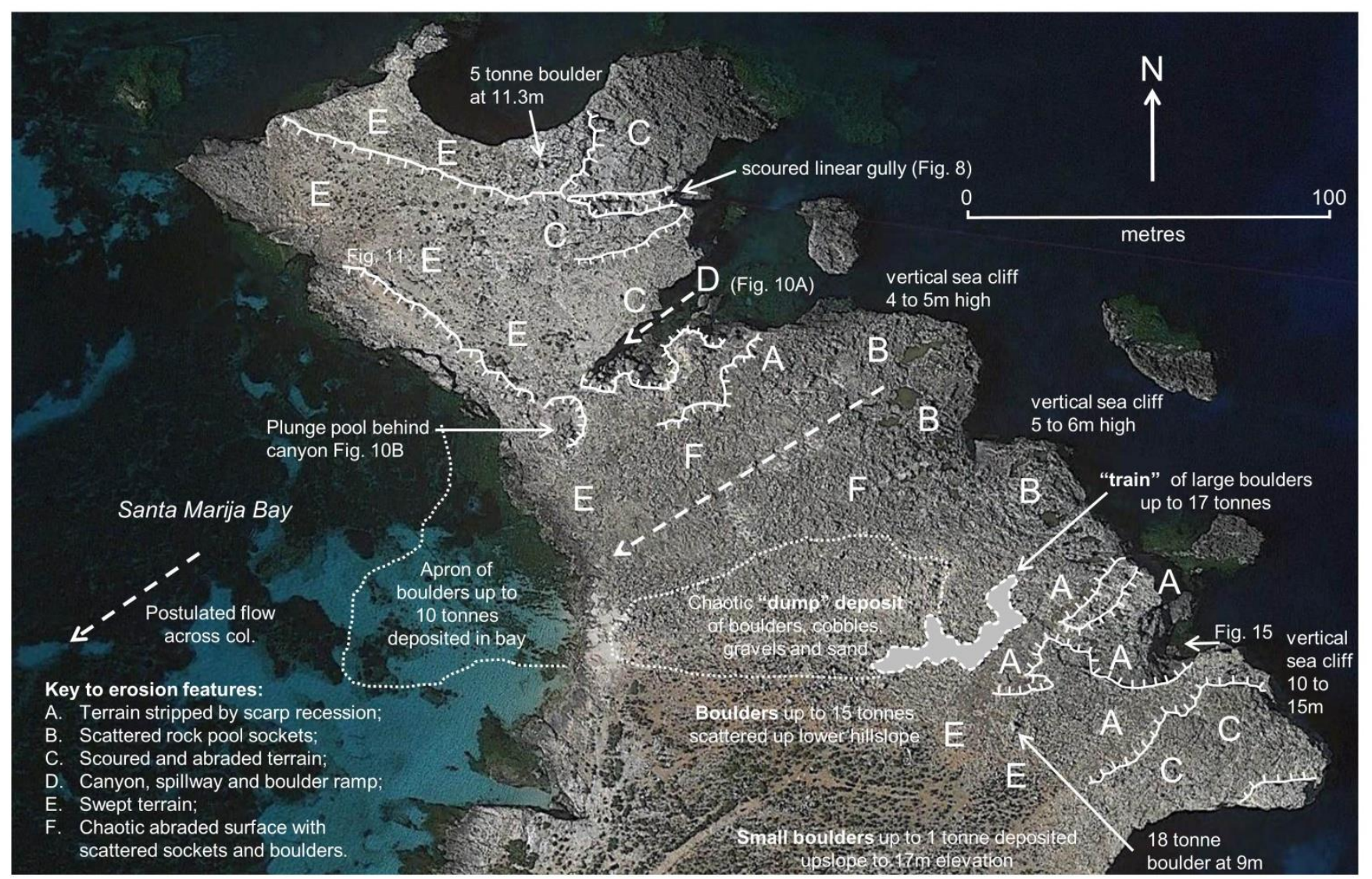


Figure 10a. A stack of boulders forms a ramp at the head of a coastal ravine open to the NE (behind the camera). Their imbricate structure indicates that they have been driven onshore by an extreme wave flow. The head of the ravine forms the lip of the spillway beyond. See Figure 9.

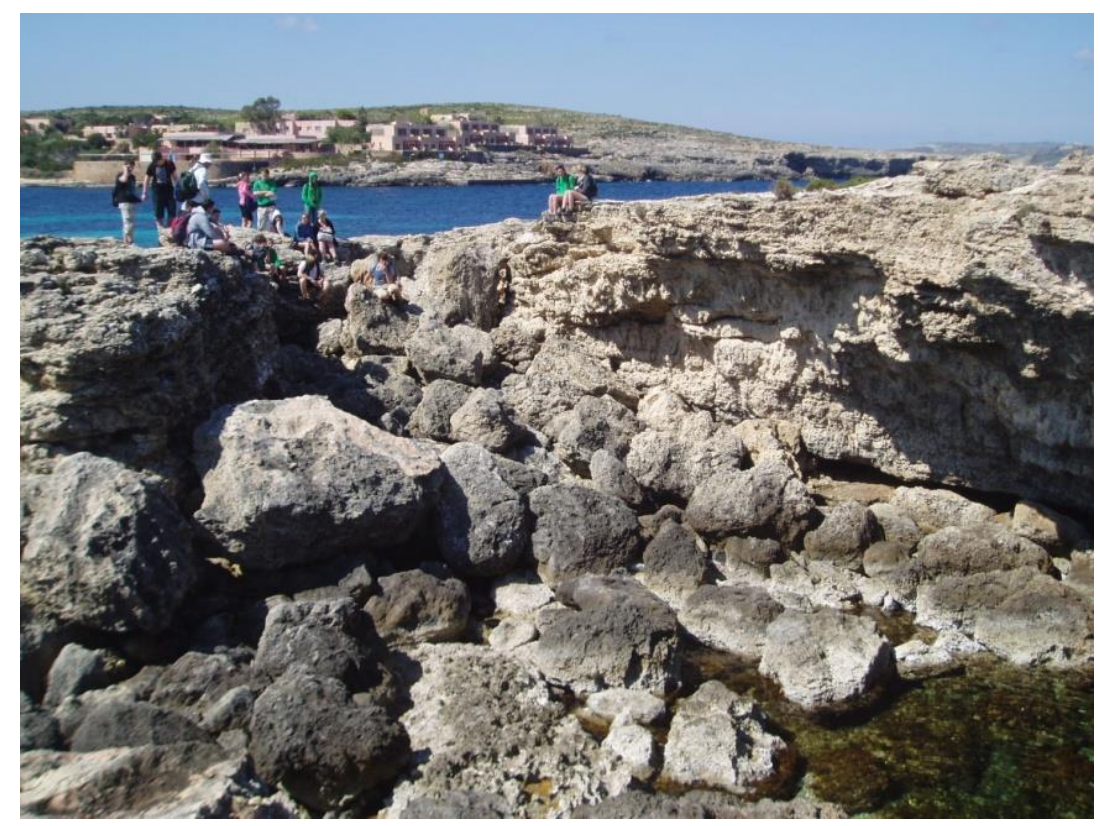

Figure 10b. A few metres beyond and in line with the head of the ravine, a hollow has been eroded out in which two large boulders now lie trapped. They have a-axis lengths of 1.8 and $1.6 \mathrm{~m}$ respectively. This is interpreted as a plunge pool formed by a high energy flow which jetted over the lip of the spillway. Beyond to the W lies Santa Marija bay where the presence of a submerged fan of large boulders marks the site of a large flow from the spillway issuing into the bay. See Figure 9.

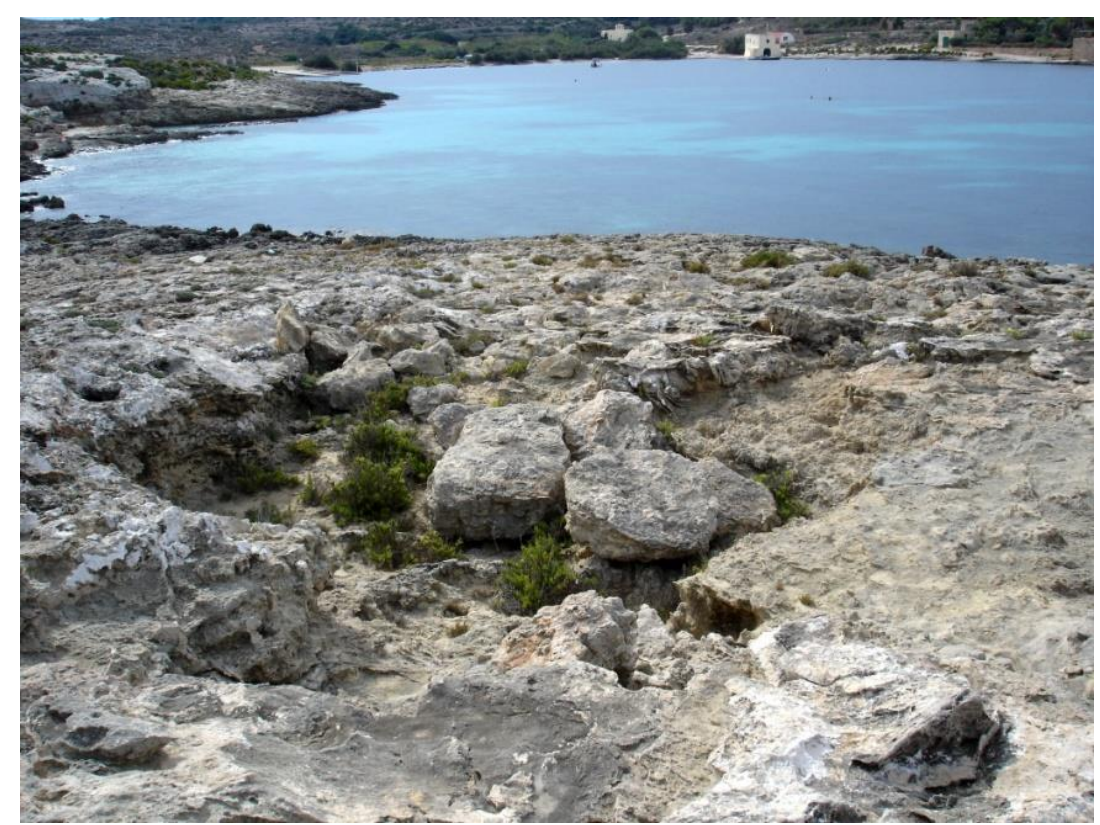


Figure 11. Swept terrain, Ghemieri. The rock surface lacks a cover of sedimentary debris yet shows no distinctive features of erosion by incision. The presence of regolith material in crevices within the rock suggests that soil and regolith were formerly more abundant here and have been swept from the surface by an erosive event. This would be consistent with overwashing by an extreme wave, as suggested by an abundance locally of other field evidence. The lack of incision and the preservation of pockets of regolith here, in contrast to other nearby land surfaces, imply that such an event may be spatially variable in its erosive impacts.

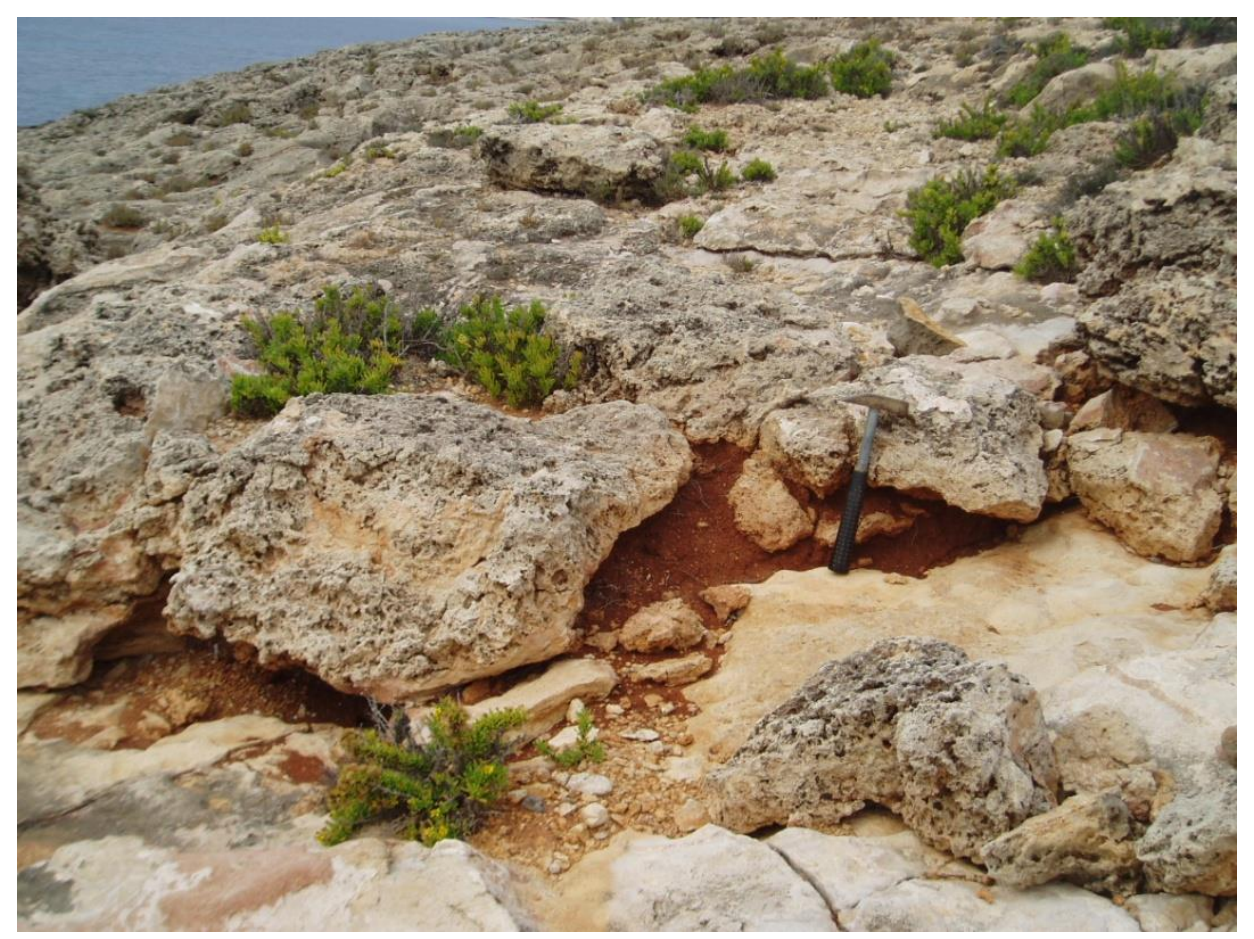


Figure 12. Height/range diagram of erosional signatures plotted by study site and lithology.

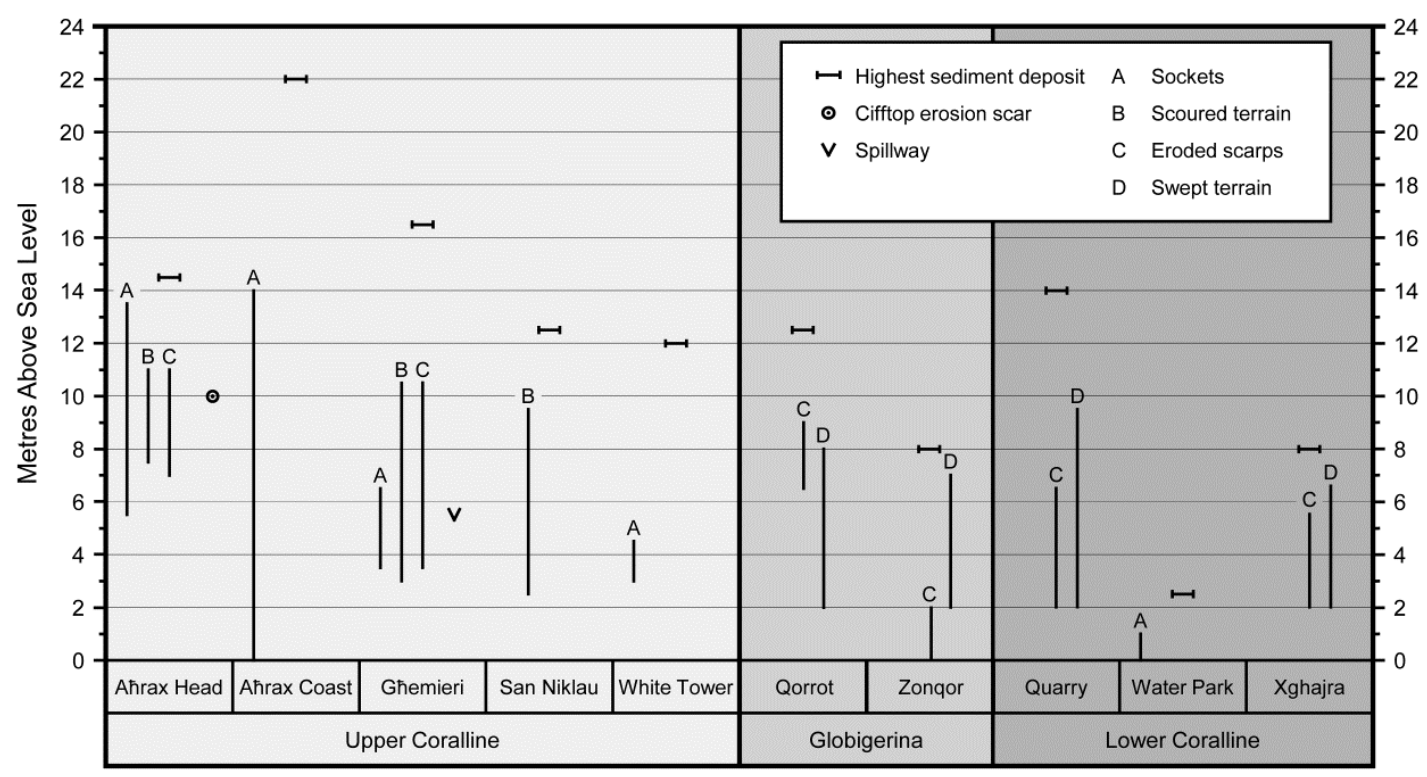


Figure 13. Tentative relationships between flow intensity and associated landforms, showing the suite of erosion features in relation to the dominant processes involved in their formation. The forms are plotted against a subjective scale of flow intensity to show the range of flow intensities likely to be responsible for their creation and development.

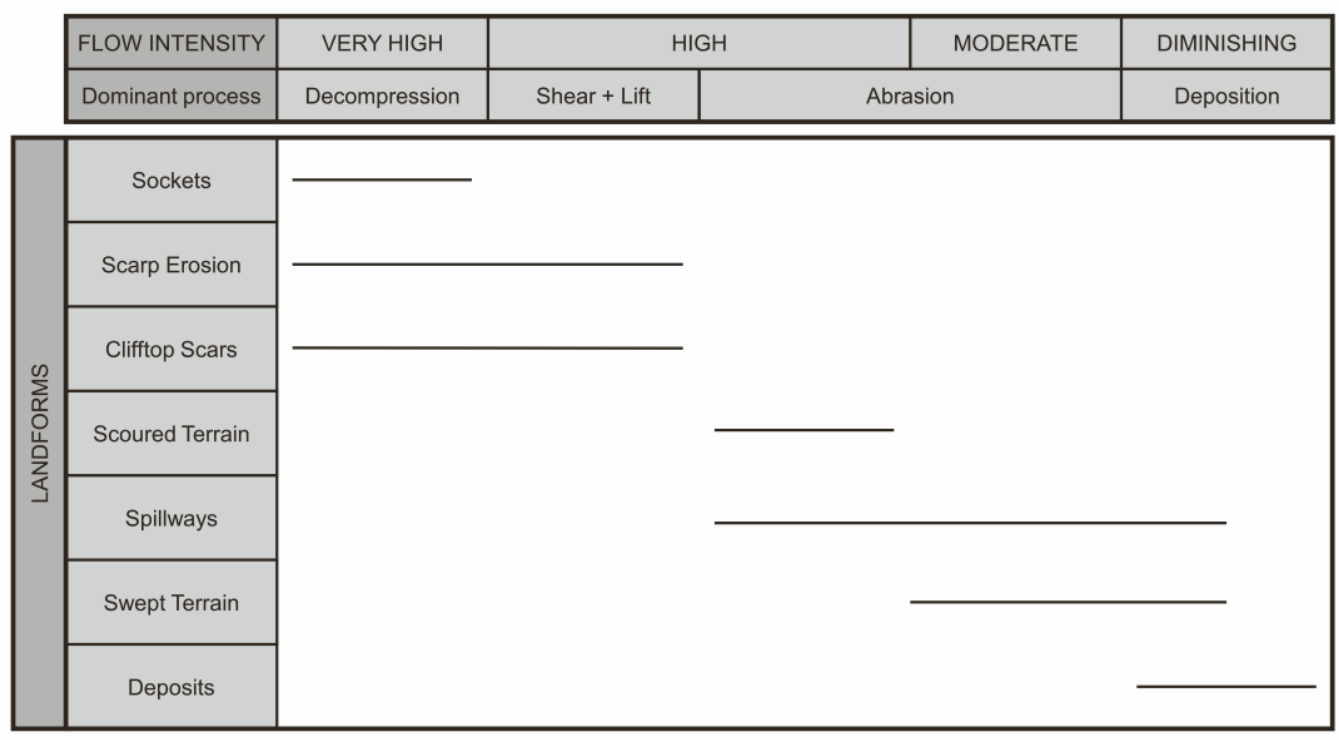


Figure 14 Composite N-S section across Ghemieri col, showing reconstructed overwashing levels numbered as follows:. 1 maximum known storm wave of $5.5 \mathrm{~m}$ is just to overtop the crest of the col. 2 large imbricate boulders on the southern hill slope and on Ghemieri summit indicate a high energy flow overwashing the peninsula to at least (11 m asl). 3 a scatter of small boulders on the southern slope suggests that the outlying overwashing flow attained a minimum level of $17 \mathrm{~m}$ asl. Flows of such magnitudes far exceed those of the highest known storm waves and would have been responsible for the significant depositional and erosional forms found on the floor of the col.

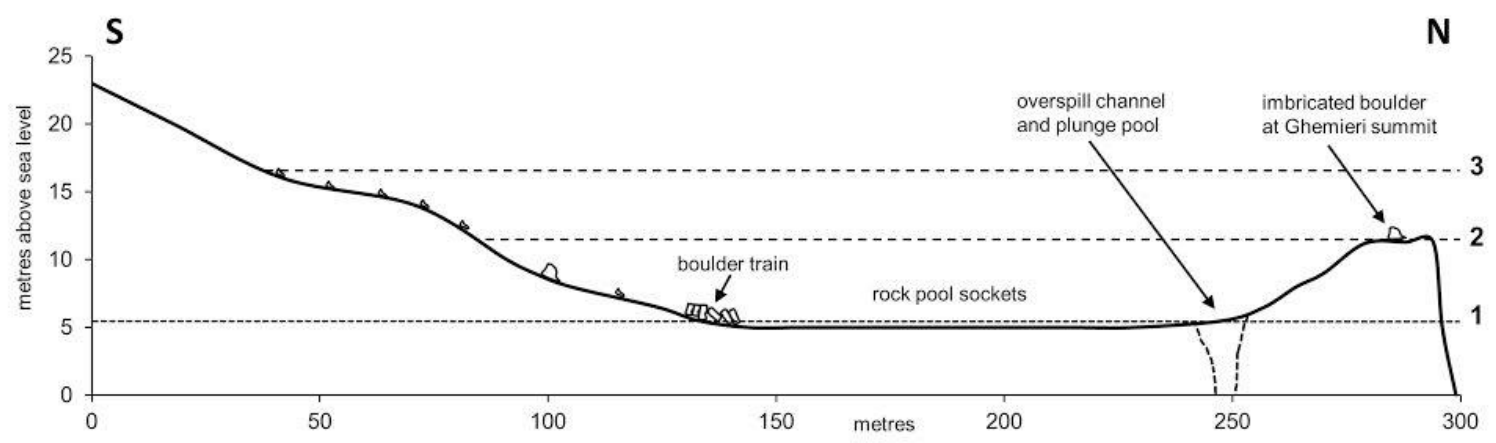

3 Postulated minimum inundation level (small boulders at up to $17 \mathrm{~m}$ );

2 Minimum level of high energy flow (large imbricated boulders at up to $11.3 \mathrm{~m}$ )

1 Crest of maximum storm wave $(5.5 \mathrm{~m})$ 
Figure 15. Ghemieri viewed from east to west across the peninsula with Santa Marija Bay and Gozo in the distance. The view follows the direction of reconstructed flow from seaward with stripped terrain and erosion scarps in the foreground and the boulder train beyond. Measurement is in progress within a socket (foreground right) and amongst the imbricate boulders of the train.

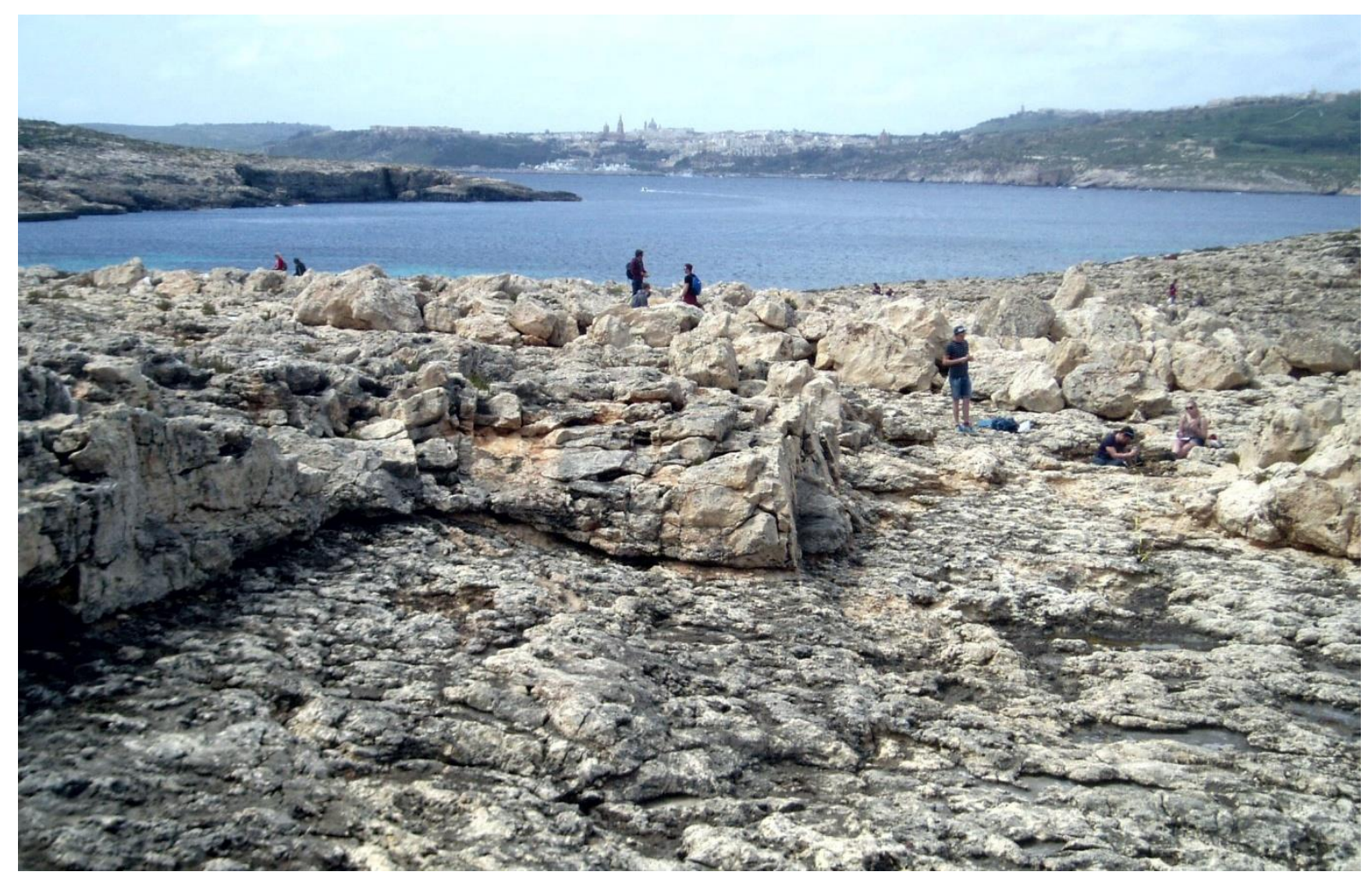

